\title{
CD33 recruitment inhibits IgE-mediated anaphylaxis and desensitizes mast cells to allergen
}

\author{
Shiteng Duan, ${ }^{1}$ Cynthia J. Koziol-White, ${ }^{2}$ William F. Jester Jr., ${ }^{2}$ Scott A. Smith, ${ }^{3}$ Corwin M. Nycholat, ${ }^{1}$ Matthew S. Macauley, ${ }^{1}$ \\ Reynold A. Panettieri Jr., and James C. Paulson' \\ 'Department of Molecular Medicine, The Scripps Research Institute, La Jolla, California, USA. ${ }^{2}$ Rutgers Institute for Translational Medicine and Science, Rutgers University, New Brunswick, \\ New Hampshire, USA. ${ }^{3}$ Department of Medicine, and Department of Pathology, Microbiology and Immunology, Vanderbilt University Medical Center, Vanderbilt University, Nashville, Tennessee, USA.
}

\begin{abstract}
Allergen immunotherapy for patients with allergies begins with weekly escalating doses of allergen under medical supervision to monitor and treat IgE mast cell-mediated anaphylaxis. There is currently no treatment to safely desensitize mast cells to enable robust allergen immunotherapy with therapeutic levels of allergen. Here, we demonstrated that liposomal nanoparticles bearing an allergen and a high-affinity glycan ligand of the inhibitory receptor CD33 profoundly suppressed lgEmediated activation of mast cells, prevented anaphylaxis in Tg mice with mast cells expressing human CD33, and desensitized mice to subsequent allergen challenge for several days. We showed that high levels of CD33 were consistently expressed on human skin mast cells and that the antigenic liposomes with CD33 ligand prevented IgE-mediated bronchoconstriction in slices of human lung. The results demonstrated the potential of exploiting CD33 to desensitize mast cells to provide a therapeutic window for administering allergen immunotherapy without triggering anaphylaxis.
\end{abstract}

\section{Introduction}

Type I hypersensitivity, or allergy, is a major public health concern worldwide (1). In the US, food allergy alone affects 15 million Americans $(2,3)$, and at least $1.6 \%$ of the population has experienced anaphylaxis (4). Mast cells play a key role in allergy and anaphylaxis through expression of the high-affinity IgE receptor (FceRI), which strongly binds allergen-specific IgE. Allergen crosslinking of the IgE-FceRI complex triggers mast cell exocytosis of preformed granules and release of additional newly synthesized mediators (5-8). Individuals with allergies typically manage their conditions by avoiding the allergens, by targeting the mediators released by mast cells, or by alleviating symptoms using an antihistamine or corticosteroid upon accidental exposure (9). A therapeutic option approved to treat severe allergic asthma is omalizumab (Xolair), an anti-IgE antibody that reduces circulating levels of IgEs and blocks circulating IgE from binding to the FceRI receptor. However, while this drug reduces sensitivity over time, patients receiving omalizumab can remain sensitive to allergens long after allergen-specific $\operatorname{IgE}$ is cleared from the serum as a result of the slow turnover of mast cells and long half-life of FceRIIgE complexes $(10,11)$. The only option for developing sustained tolerance is allergen immunotherapy, which, given the risk of anaphylaxis, requires months to years of administration of allergen in escalating graded doses under medical supervision (12). Even though allergen immunotherapy is sometimes effective in pro-

Related Commentary: p. 955

Conflict of interest: The authors have declared that no conflict of interest exists. License: Copyright 2019, American Society for Clinical Investigation.

Submitted: October 10, 2018; Accepted: January 8, 2019.

Reference information: / Clin Invest. 2019;129(3):1387-1401.

https://doi.org/10.1172/JCl125456. ducing sustained unresponsiveness to allergens, most patients withdraw because of the prolonged regimen or because of adverse symptoms, including anaphylaxis, during treatment, before reaching a therapeutic dose (12). Clearly, a method for introducing a therapeutic amount of allergen into a sensitized individual without the risk of anaphylaxis would be a major breakthrough in allergen immunotherapy (12-14).

Mast cells express a number of inhibitory receptors bearing immunoreceptor tyrosine-based inhibitory motifs (ITIMs), which can recruit tyrosine phosphatases and interrupt the kinase-driven signaling cascades, preventing mast cell degranulation and cytokine production $(9,14,15)$. A promising approach to inhibit mast cell activation involves strategies that ligate inhibitory receptors to the IgE-FceRI complex. For example, bispecific antibodies that bind IgE and an inhibitory receptor (Fc $\gamma \mathrm{RIIb}$ or CD300a) effectively reduced mast cell activation induced by subsequent allergen challenges in mouse models of anaphylaxis (16-19). A variation of this strategy involves a chimeric fusion protein that fuses allergen (Fel d 1 or Ara h 2 [Ah2]) to a single chain antibody targeting the Fc $\gamma$ RIIb receptor, which can block mast cell activation in mouse models of anaphylaxis $(20,21)$.

Several members of the inhibitory sialic acid-binding immunoglobulin-like lectins (Siglec) family have also been reported to be expressed on human mast cells and include CD33 (Siglec-3) on human lung mast cells (22) and Siglec $-5,-6$, and -8 on CD $34^{+}$cellderived mast cells (23). Since all of these Siglecs contain ITIMs in their cytoplasmic domain $(24,25)$, they represent alternatives for the use of inhibitory receptors to suppress mast cell degranulation. With the goal of recruiting Siglecs to the FceRI receptor on mast cells, we recognized that a nanoparticle platform we developed for the suppression of $\mathrm{B}$ cell activation might be adapted to mast cells. For B cells, liposomal nanoparticles that displayed both an antigen and a high-affinity ligand for a B cell Siglec (CD22 or Siglec-G) 
strongly suppressed B cell activation by recruiting the Siglec to the immunological synapse with the B cell receptor. Furthermore, it induced an apoptotic signal that eliminated the antigen-specific $B$ cells from the B cell repertoire, leading to immunological tolerance of the mouse to subsequent antigen challenge (26-29).

We reasoned that antigenic liposomes bearing an allergen and glycan ligand of a mast cell-inhibitory Siglec might similarly result in recruitment to the IgE-FceRI complex and suppress mast cell degranulation (Figure 1A). Here, we show that antigenic liposomes containing a high-affinity ligand for human CD33 prevent antigen-mediated degranulation of human mast cells. In Tg mice expressing CD33 on mast cells, antigenic liposomes with CD33 ligand (CD33L) profoundly suppressed IgE-mediated mast cell activation in passive cutaneous and passive systemic models of anaphylaxis. Moreover, these animals are completely protected from anaphylaxis induced by subsequent antigen challenges as a result of reduced antigen-specific IgE on mast cells and accelerated clearance of antigen-specific IgE from the blood. Thus, the inhibitory properties of human CD33 can be exploited to desensitize mast cells, offering new treatment strategies for allergen immunotherapy.

\section{Results}

CD33 ligands displayed on antigenic liposomes suppress IgE-dependent degranulation of mast cells. To test the nanoparticle platform for suppressing mast cell activation, we used the human LAD2 mast cell line, which expresses CD33 and several other human Siglecs (Figure 1B). For liposomal nanoparticles formulated to display both antigen and CD33L, we selected trinitrophenol (TNP) as the antigen and a CD33L comprising a sialic acid analog with substituents on the sialic acid at the C-9 and C- 5 positions that binds to CD33 with high affinity and selectivity (30). CD33L and TNP were covalently coupled to PEGylated lipid-1,2-distearoyl-sn-glycero3-phosphoethanolamine (PEG-DSPE) (Supplemental Figure 1, A and $\mathrm{B}$; supplemental material available online with this article; https://doi.org/10.1172/JCI125456DS1). Liposomes with TNP only (TNP-LP), CD33L only (LP-CD33L), or both (TNP-LP$\mathrm{CD} 33 \mathrm{~L}$ ) were prepared by mixing all lipids prior to hydration and extrusion through controlled pore membranes $(26,30)$.

Liposomes with CD33L containing Alexa Fluor 647-conjugated (AF647-conjugated) lipid (Supplemental Figure 1C) bound strongly to CD33 expressed on Chinese hamster ovary (CHO) cells, but not to cells expressing CD33 without the conserved arginine (R119A) required for ligand binding (Supplemental Figure 1, D and E), or to $\mathrm{CHO}$ cells expressing various murine Siglecs (Supplemental Figure 1F). We observed that liposomes with CD33L bound strongly to LAD2 cells and that binding was blocked with CD33-blocking antibodies (Figure 1C and Supplemental Figure 1, G and $\mathrm{H}$ ).

To evaluate the impact of the CD33L on antigen-induced mast cell activation, we sensitized LAD2 cells with anti-TNP-IgE. Using calcium flux as a measure of activation, TNP-LP induced strong activation, and addition of the CD33 ligand TNP-LP-CD33L strongly suppressed activation (Figure 1D). Similarly, we found that TNP-LP strongly induced degranulation of LAD2 cells, as measured by the release of $\beta$-hexosaminidase ( $\beta$-hex), which was suppressed when CD33L was present (Figure 1E).
To further assess the importance of presenting the antigen and CD33L on the same liposome, we compared TNP-LP, TNP-LPCD33L, and a mixture of TNP-LP and liposomes containing only CD33L (LP-CD33L). While CD33L strongly suppressed degranulation when TNP and CD33L were presented on the same liposome (TNP-LP-CD33L), it had no significant inhibition of degranulation when present on separate liposomes (LP-CD33L) (Figure $1 F)$. Furthermore, pretreatment of LAD2 cells with LP-CD33L had no impact on degranulation induced by TNP-LP, but promoted degranulation by TNP-LP-CD33L, negating the inhibitory impact of CD33L on the same liposome (Figure $1 \mathrm{G}$ ). Likewise, pretreatment of LAD2 cells with anti-CD33 antibodies neither enhanced nor inhibited degranulation induced by TNP-LP, but promoted degranulation by TNP-LP-CD33L (Figure 1H and Supplemental Figure 2, A-C). These results suggest that prior addition of antiCD33 or LP-CD33L ligates and sequesters CD33 and prevents its recruitment to the IgE-FceRI complex by TNP-LP-CD33L, preventing the suppression of activation and degranulation by CD33L.

To test the generality to common food allergens, the major peanut allergen Ah2 and OVA were coupled to PEGylated lipid $(26,28)$. Because of the formulation, a density of 0.1 mole percentage of either PEGylated protein allergen was formulated into liposomes as Ah2-LP or OVA-LP with or without CD33L. Unlike TNP-LP, Ah2-LP and OVA-LP were able to induce maximum 15\%-17\% degranulation using LAD2 cells sensitized with atopic human serum from peanut-sensitized patients (PlasmaLab) or anti-OVA-IgE (clone 11B6), respectively. We attribute the lower extent of degranulation to reduced allergen cross-linking due to the lower density of the antigen compared with $0.4 \%$ TNPPEG-DSPE. However, in both cases, degranulation was strongly suppressed if the CD33L was copresented with the antigen (Ah2LP-CD33L or OVA-LP-CD33L) (Figure 1, I and J). Pretreatment of LAD2 cells using anti-CD33 antibodies neither enhanced nor inhibited degranulation induced by OVA-LP, but permitted degranulation induced by OVA-LP-CD33L, suggesting that antiCD33 blocks recruitment of CD33 to the anti-OVA-IgE-FceRI complex. (Supplemental Figure 2D).

We next asked whether treatment with TNP-LP-CD33L desensitized LAD2 cells to subsequent antigen challenge. LAD2 cells sensitized with anti-TNP-IgE were pretreated with buffer control or TNP-LP-CD33L for 1 hour, followed by washing and challenge with TNP-BSA (Biosearch Technologies). Cells pretreated with buffer alone showed a strong induction of degranulation, while those pretreated with TNP-LP-CD33L were completely desensitized to challenge by TNP-BSA (Supplemental Figure 3A).

To determine whether desensitization was antigen specific, we sensitized LAD2 cells with both anti-TNP-IgE and anti-OVAIgE. The cells were first treated with buffer or TNP-LP-CD33L and then challenged with soluble OVA. Pretreatment with TNPLP-CD33L partially inhibited degranulation induced by OVA (Supplemental Figure 3B), suggesting that desensitization was at least partially antigen specific (31). Using cells sensitized with both anti-TNP-IgE and anti-OVA-IgE, we assessed the amount of these IgEs remaining on the surface of mast cells using fluorescent TNP-LP (AF488) and OVA-LP (AF647) following treatment of the cells with TNP-LP, TNP-LP-CD33L, or LP-CD33L. We found that prior treatment of cells with TNP-LP or TNP-LP-CD33L abolished 

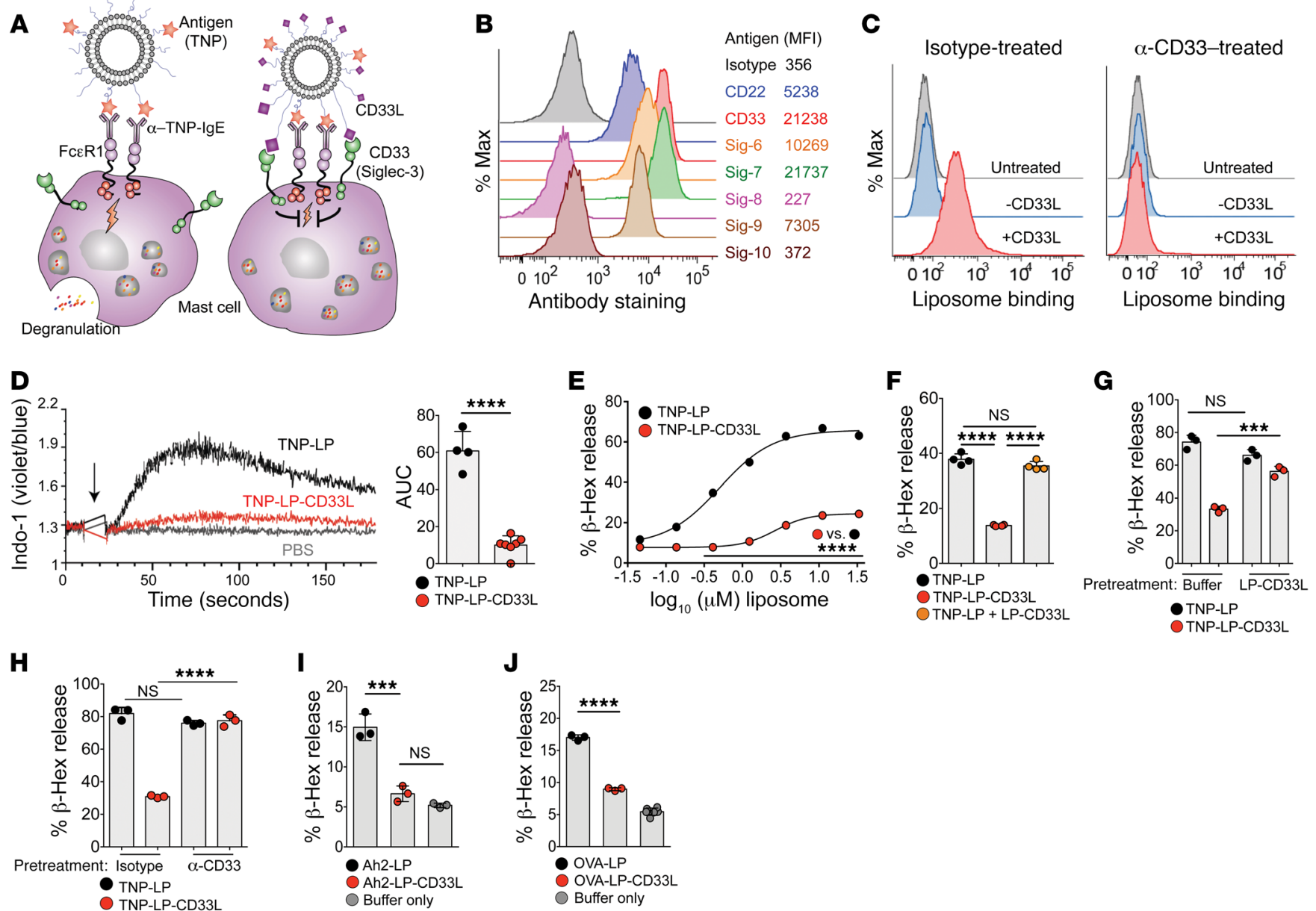

Figure 1. Display of CD33L on antigenic liposomes suppresses IgE-dependent degranulation of LAD2 cells. (A) Schematic representation of an antigenic liposome (TNP-LP, left) or an antigenic liposome displaying human CD33 ligands (TNP-LP-CD33L, right). (B) Antibody staining of various Siglecs (Sig-) on LAD2 cells analyzed by flow cytometry. (C) Flow cytometric analysis of binding of fluorescent liposomes with or without CD33L (20 $\mu$ M) to LAD2 cells pretreated with isotype control or anti-CD33 (clone WM53). (D) Calcium flux of LAD2 cells induced by addition (arrow) of TNP-LP or TNP-LP-CD33 (2.5 $\mu$ M) or PBS $(1 \mu \mathrm{l})$. Graph shows quantification of the AUC of calcium flux induced by $2.5 \mu \mathrm{M}$ TNP-LP or TNP-LP-CD33L. Results were combined from 2 independent experiments. (E) Degranulation induced by TNP-LP or TNP-LP-CD33L as measured by the percentage of $\beta$-hex release ( $n=3$ per condition; values are plotted as the mean \pm SD). (F) Degranulation induced by TNP-LP (30 $\mu \mathrm{M})$, TNP-LP-CD33L (30 $\mu \mathrm{M})$, or a mixture of TNP-LP and LP-CD33L (30 $\mu$ M each). (C) Degranulation induced by TNP-LP or TNP-LP-CD33L $(30 \mu \mathrm{M})$ in the presence of LP-CD33L $(10 \mu \mathrm{M})$. Control cells received buffer only. (H) Degranulation induced by TNP-LP or TNP-LP-CD33L $(30 \mu \mathrm{M})$ in the presence of isotype or anti-CD33 (clone WM53, $1 \mu \mathrm{g} / \mathrm{ml}$ ). (I) Degranulation induced by Ah2-LP or Ah2-LP-CD33L $(30 \mu \mathrm{M})$, with final Ah2 at $750 \mathrm{ng} / \mathrm{ml}$ using LAD2 cells sensitized with atopic plasma reactive to peanut (PlasmaLab). (J) Degranulation induced by OVA-LP or OVA-LP-CD33L $(30 \mu \mathrm{M})$, with the final OVA dose at $1.5 \mu \mathrm{g} / \mathrm{ml}$ using LAD2 cells sensitized with human anti-OVA-IgE. Results in E-J are representative of 3 independent experiments. ${ }^{* *} P<0.001$ and ${ }^{* * *} P<0.0001$, by 2 -tailed Student's $t$ test (D and E) and 1-way ANOVA followed by Tukey's test (F-J). $\alpha$, anti; Max, maximum.

binding of TNP-LP (AF488) but had no impact on binding of OVALP (AF647) (Supplemental Figure 3C). Also, prior treatment with LP-CD33L had no impact on binding of either TNP-LP or OVA-LP. The results show that exposure to an antigenic (TNP) liposome either blocked or caused endocytosis of the respective IgE-FceRI complex but had no effect of the surface presentation of an IgE to another antigen $(32,33)$.

$\mathrm{Tg}$ mice with mast cells expressing functional human CD33. In order to evaluate the impact of antigenic nanoparticles with CD33L in mouse models of anaphylaxis, we developed a Rosa26-Stop $p^{f / f_{-}}$ CD33-Tg mouse. cDNA encoding full-length human CD33 (GenBank: BC028152.1) was inserted into the Rosa26 locus through homologous recombination in PRX embryonic stem (ES) cells from a C57BL/6N background (34). The translation of CD33 under the CAG promoter was controlled by a Stop ${ }^{f / f l}$ cassette placed upstream of $\mathrm{CD} 33$, and translation could be monitored by a frt-flanked IRES-EGFP cassette placed downstream of CD33 (Supplemental Figure 4A). Insertion of the transgene into the Rosa26 locus was confirmed by both Southern blotting and PCR (Supplemental Figure 4, B and C). Mice with germline transmission of the Rosa26-Stop ${ }^{f / f}-C D 33$ gene were maintained on a C57BL/6 background. To express CD33 on mast cells, the Rosa26-Stop ${ }^{f / f l}-C D 33-$ $\mathrm{Tg}$ mice were crossed with Mcpt5-Cre mice $(35,36)$. Mice bearing the $\mathrm{Mcpt5}-\mathrm{Cr} \mathrm{e}^{+/-} \mathrm{R} 26-\mathrm{CD} 33^{+}$genotype are referred to hereafter as CD33-Tg mice. Unless otherwise stated, Mcpt5-Cre-R26-CD33 ${ }^{+}$ littermates were used as controls (control-Tg mice).

To characterize the expression of $\mathrm{CD} 33$, we analyzed peritoneal cells by flow cytometry. Compared with peritoneal mast cells 
A
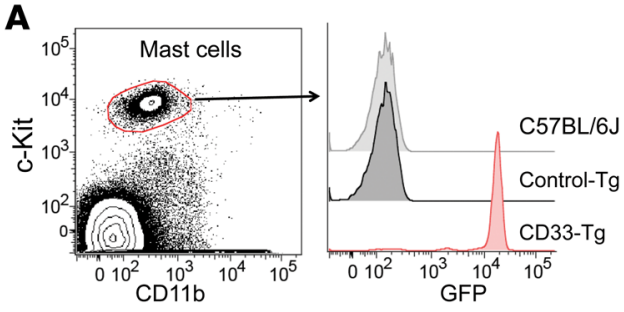

D
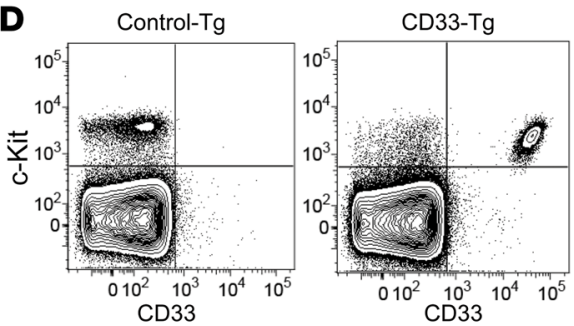

B

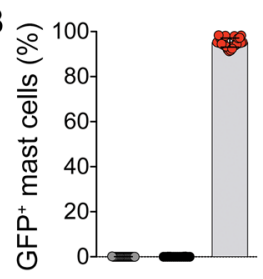

E
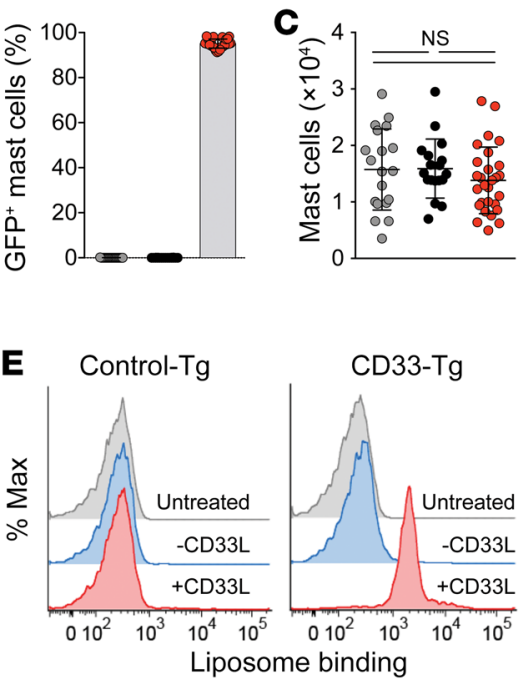

$\mathbf{F}$

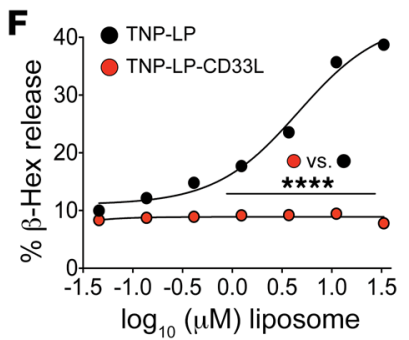

C57BL/6J, $n=19$

- Control-Tg, $n=18$

(Mcpt5-Cre- Rosa26-Stop ${ }^{\text {itit-CD33 }}$ )

CD33-Tg, $n=28$

(Mcpt5-Cre ${ }^{+/-}$Rosa26-Stop ${ }^{f / 1+}-C D 33^{+}$)

G
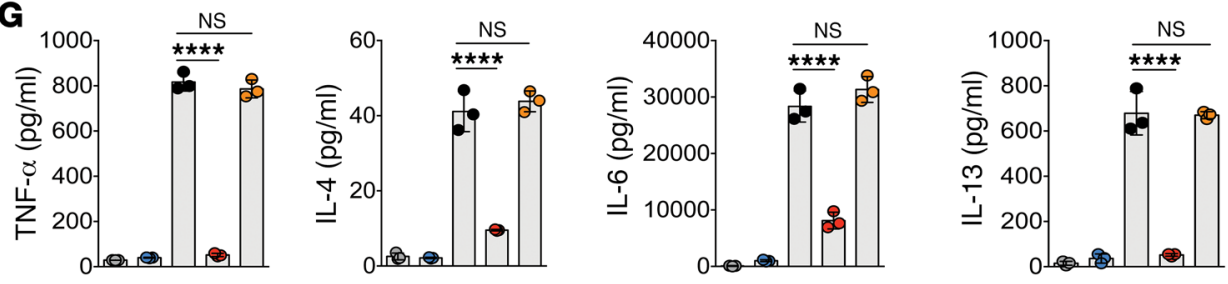

H

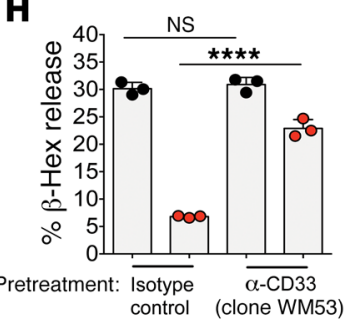

I

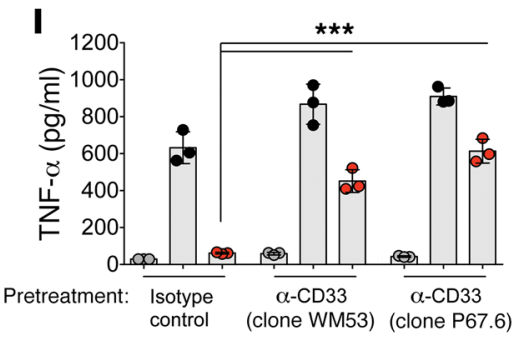

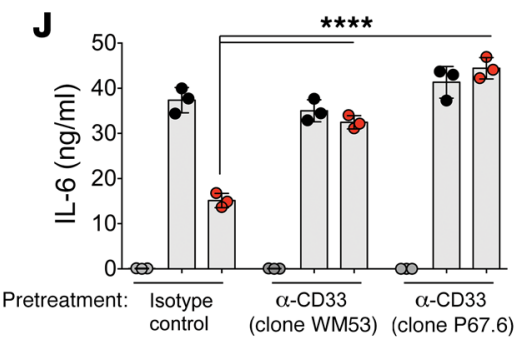

Figure 2. Tg mice with mast cells expressing functional human CD33. (A) Flow cytometric analysis of GFP expression on representative peritoneal mast

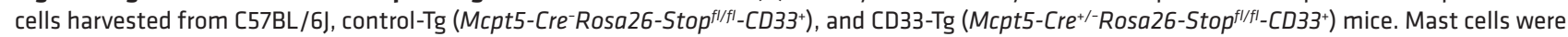
defined as $\mathrm{Pl}^{-} \mathrm{CD}_{4}{ }^{+} \mathrm{c}-\mathrm{Kit}^{+}$. Baseline GFP signal was determined by mast cells from C57BL/6) mice. (B) Quantification of the percentage of GFP+ peritoneal mast cells from mice of the 3 genotypes. Tg mice bearing 1 or 2 copies of CD33 were used. Both male and female mice 8 weeks or older were analyzed, with no difference observed. (C) Numbers of peritoneal mast cells from the same mice of the 3 genotypes as in B. (A-C) Results were compiled from 6 experiments. (D) Staining of peritoneal cells harvested from control-Tg or CD33-Tg mice with anti-CD33 (clone WM53) or isotype control, as analyzed by flow cytometry. (E) Binding of fluorescent liposome, with or without CD33L $(20 \mu \mathrm{M})$, to peritoneal mast cells (c-Kit $\left.{ }^{+} \mathrm{F} c \varepsilon R \mathrm{I}^{+} \mathrm{CD} 45^{+}\right)$. (F) Degranulation of CD33 BMMCs induced by TNP-LP or TNP-LP-CD33L. (C) Cytokine induction of CD33+ BMMCs following treatment with TNP-LP (40 $\mu$ M), TNP-LP-CD33L $(40 \mu \mathrm{M})$, LP-CD33L $(40 \mu \mathrm{M})$, or a mixture of TNP-LP and LP-CD33L (40 $\mu \mathrm{M}$ each). Supernatant from the unstimulated cells was subtracted as a background. (H) Degranulation of CD33+ BMMCs induced by TNP-LP or TNP-LP-CD33L (30 $\mu \mathrm{M})$ in the presence of anti-CD33 (2 $\mu \mathrm{g} / \mathrm{ml})$. (I and J) Cytokine production of CD33+ BMMCs induced by TNP-LP or TNP-LP-CD33L $(40 \mu \mathrm{M})$ in the presence of anti-CD33 $(10 \mu \mathrm{g} / \mathrm{ml})$. Supernatant from untreated cells was subtracted as a background. Results shown are representative of $3(\mathbf{D}-\mathbf{G})$ or $2(\mathbf{H}-\mathbf{J})$ independent experiments. (F-J) Values are plotted as the mean \pm SD ( $n=3$ per condition). ${ }^{* *} P<0.001$ and ${ }^{* * * *} P<0.0001$, by 2-tailed Student's t test $(\mathbf{F})$ and 1-way ANOVA followed by Tukey's test (C and G-J).

from C57BL/6J mice, control-Tg mice showed no expression of the transgene as evidenced by the lack of GFP expression, but $90 \%$ of the mast cells from CD33-Tg mice were $\mathrm{GFP}^{+}$(Figure 2, A and B). We found that control-Tg and CD33-Tg mice had similar mast cell numbers compared with the numbers detected in C57BL/6J mice (Figure 2C). Consistent with GFP expression, CD33 was expressed on peritoneal mast cells from CD33-Tg mice but not on other cell types from CD33-Tg mice or on any cells from control-Tg mice (Figure 2D). In contrast to human mast cells, which express several human Siglecs, peritoneal mast cells and bone marrow-derived mast cells (BMMCs) from C57BL/6J mice did not express detectable murine CD33 or any other murine Siglec (Supplemental Figure 4, D and E). Fluorescent liposomes with CD33L bound strongly to peritoneal mast cells from CD33-Tg mice but did not bind to mast cells from control-Tg mice (Figure 2E).

To determine whether CD33 was functional in murine mast cells, BMMCs from CD33-Tg mice were prepared with IL-3-conditioned media (37). After 4 weeks of culturing, more than $90 \%$ of the cells were c-Kit ${ }^{+} \mathrm{Fc} \varepsilon \mathrm{RI}^{+}$and $20 \%-50 \%$ were $\mathrm{CD} 33^{+} \mathrm{GFP}^{+}$ (Supplemental Figure 4F). These cells were then sorted to obtain 
$100 \% \mathrm{GFP}^{+} \mathrm{BMMCs}$ for in vitro experiments. Fluorescent liposomes with CD33L bound to $\mathrm{GFP}^{+}$BMMCs but did not bind to GFP- BMMCs (Supplemental Figure 4, G and H).

In BMMCs sensitized with anti-TNP-IgE, we observed that TNP-LP strongly induced degranulation, but with copresentation of the CD33L (TNP-LP-CD33L), we found that degranulation was profoundly suppressed (Figure 2F). Similarly, induced release and production of TNF- $\alpha$, IL-4, IL- 6 , and IL-13 by TNP-LP were strongly suppressed by copresentation of CD33L (Figure 2G). In contrast, CD33 on separate liposomes (LP-CD33L) did not enhance or inhibit TNP-LP-induced cytokine production (Figure 2G). Likewise, monoclonal anti-CD33 antibodies (clones P67.6 and WM53) neither caused cytokine production by themselves nor inhibited TNPLP-induced degranulation or cytokine production, but rather permitted the induction of degranulation and cytokine production by TNP-LP-CD33L, abrogating the suppression mediated by CD33L (Figure 2, H-J). These results show that human CD33 functions as an inhibitory receptor on murine mast cells in a manner similar to that observed with human LAD2 cells (Figure 1).

Recruitment of CD33 suppresses IgE/FcERI signaling. Antigenmediated aggregation of IgE-FceRI stabilizes the IgE-FceRI complex in lipid rafts with Src kinases that initiate the signaling cascade (38). The immunoreceptor tyrosine-based activation motifs (ITAMs) in the cytoplasmic tails of the FceRI receptor, when phosphorylated by Src kinases, recruit splenic tyrosine kinase (Syk), which leads to the phosphorylation of downstream kinases (7). To assess the role of CD33 recruitment on the signaling cascade, we performed Western blot analysis of selected kinases that result in degranulation (PLC $\gamma-1$ and PLC $\gamma-2)$ and cytokine production (MEK, ERK, JNK, and AKT) $(7,39,40)$. Indeed, we found that TNP-LP strongly induced Syk phosphorylation using LAD2 cells or $\mathrm{CD}_{3} 3^{+}$murine BMMCs sensitized with anti-TNP-IgEs. Recruitment of CD33 (TNP-LP-CD33L) resulted in a partial reduction of Syk phosphorylation in LAD2 cells (Figure 3, A and B) and CD $33^{+}$ BMMCs (Figure 3C), which led to a profound reduction in phosphorylation of downstream kinases. LP-CD33L did not induce phosphorylation of any kinases in either LAD2 cells (Figure 3B) or BMMCs (Figure 3C), demonstrating that ligation of CD33 alone did not initiate or suppress signaling.

The results suggest that CD33 and FceRI are not colocalized in the same membrane microdomain and that CD33 does not constitutively suppress FceRI signaling (Figure 3D). We propose that when CD33 is recruited to the lipid rafts of the IgE-FceRI complex by CD33L on antigenic liposomes, the cytoplasmic ITIMs of CD33 are phosphorylated by local Src kinases, resulting in the recruitment of tyrosine phosphatases such as Shp-1 $(41,42)$, which dephosphorylate kinases involved in the FceRI signaling cascade (Figure 3E). Monoclonal anti-CD33 antibodies (or LP-CD33L) block the recruitment of CD33 to IgE-FceRI, thereby enabling TNP-LP-CD33Linduced mast cell activation (Figure 1, F-H, and Figure 3F).

Suppression of IgE-mediated anaphylaxis. To determine whether antigenic liposomes with CD33L could suppress mast cell activation in vivo, we used a passive cutaneous anaphylaxis (PCA) model. Mice were sensitized in 1 ear with anti-TNP-IgE, while the other ear received a PBS mock injection. The next day, the mice were given liposomes in Evans blue dye (Figure 4A). In mice with mast cells that do not express CD33 (control-Tg and Mcpt5-

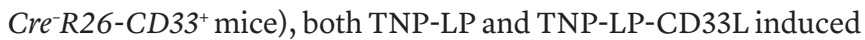
vascular leakage in ears sensitized with anti-TNP-IgE (Figure 4, $\mathrm{B}$ and $\mathrm{C})$. In contrast, in mice with mast cells expressing CD33 (CD33-Tg and $\mathrm{Mcpt5}-\mathrm{Cr} \mathrm{C}^{+/-} \mathrm{R} 26-\mathrm{CD} 33^{+}$mice), TNP-LP induced vascular leakage in ears sensitized with anti-TNP-IgE, but TNPLP formulated with CD33L (TNP-LP-CD33L) produced no significant vascular leakage in anti-TNP-IgE-sensitized ears (Figure 4, $\mathrm{D}$ and $\mathrm{E}$ ). The results demonstrate that local mast cell activation is prevented when CD33L is codisplayed with antigen.

We used a passive systemic anaphylaxis (PSA) model to assess global mast cell activation. Mice were sensitized with anti-TNP$\mathrm{IgE}$, and the next day baseline rectal temperatures were measured, and mice were treated with liposomes (Figure 4F). We observed that TNP-LP strongly induced a decrease in rectal temperature that was dependent on the amount of anti-TNP-IgE given in the sensitization step and the dose of TNP-LP in the challenge step (Supplemental Figure 5, A and B). Mice remained sensitized to TNP-LP if the challenge was delayed for 7 days (Supplemental Figure 5C).

The impact of the CD33 ligand was minimal in mice with no expression of CD33 (control-Tg mice), since both TNP-LP and TNP-LP-CD33L induced a similar degree of systemic anaphylaxis (Figure 4G). In CD33-Tg mice, TNP-LP induced a degree of anaphylaxis similar to that seen in control-Tg mice (Supplemental Figure 5D). In contrast, TNP-LP-CD33L did not trigger systemic anaphylaxis in CD33-Tg mice (Figure $4 \mathrm{H}$ and Supplemental Figure $5 \mathrm{E}$ ), demonstrating potent CD33L-mediated suppression of mast cell degranulation and anaphylaxis.

To investigate whether the tyrosine phosphatase Shp-1 is involved in CD33/CD33L-mediated inhibition of mast cell degranulation, CD33-Tg (Mcpt5-Cre ${ }^{+/-}$R26-CD33+) mice were mated with $P_{t p n} 6^{f / / f l}$ mice (43). Since Ptpn $6^{f / f l}$ mice produce no Shp-1 if cells express Cre recombinase, breeding Ptpn $6^{f / f l}$ mice with CD33$\mathrm{Tg}$ mice results in deletion of Shp-1 only in mast cells (CD33-Tg SHP-1-KO mice). As seen in Figure 4I, while TNP-LP-CD33L produced no anaphylaxis in $\mathrm{CD} 33-\mathrm{Tg}$ mice, it induced a level of anaphylaxis in the CD33-Tg Shp-1-KO mice that was similar to that induced in the control-Tg mice that expressed no CD33 (Figure 4I). These results suggest that Shp-1 plays a key role in CD33mediated inhibition of mast cell degranulation (Figure 3E).

Antigenic liposomes with CD33 ligand desensitize mice to antigen challenge. We next assessed whether antigenic liposomes with CD33L could prevent anaphylaxis upon subsequent antigen challenge in the PSA model. Initial experiments varying the dose of TNP-LP-CD33L and time of antigen challenge demonstrated that profound desensitization could be achieved (Supplemental Figure 6, A and B). Optimal desensitization could be achieved with a single dose of TNP-LP-CD33L (containing $450 \mu \mathrm{g}$ lipids and 600 pmol TNP) (Figure 5A). Treatment of TNP-LP-CD33L was well tolerated, without a significant decrease in rectal temperature, and subsequent challenges with TNP-LP caused no anaphylaxis, including challenge 24 hours later with a high dose of antigen (1\% TNP-LP) that caused death in 7 of 9 untreated mice (Figure 5B).

We next assessed the ability of antigenic liposomes with CD33L to desensitize mice to a common egg allergen, OVA (Gal d 2) (44) (Supplemental Figure 6C). In mice sensitized with anti-OVA-IgE, treatment with OVA-LP-CD33L (containing $150 \mu \mathrm{g}$ lipid and $9 \mu \mathrm{g}$ OVA) did not cause significant anaphylaxis, and subsequent chal- 
A

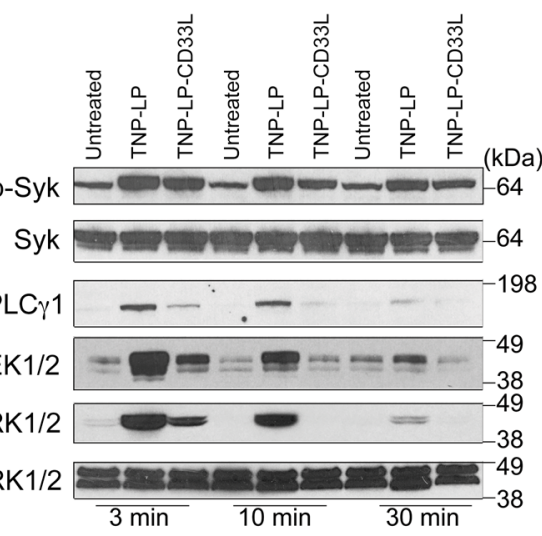

B

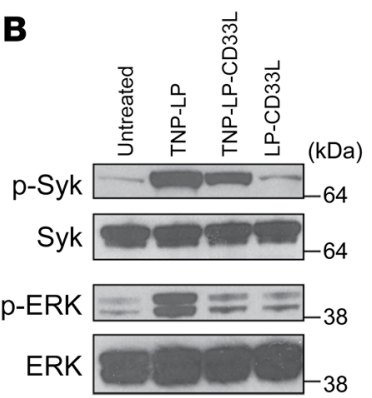

C

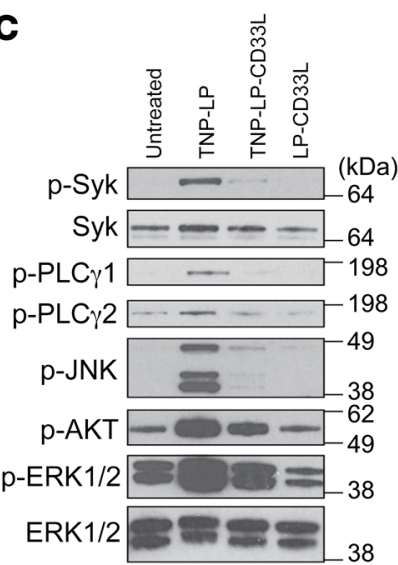

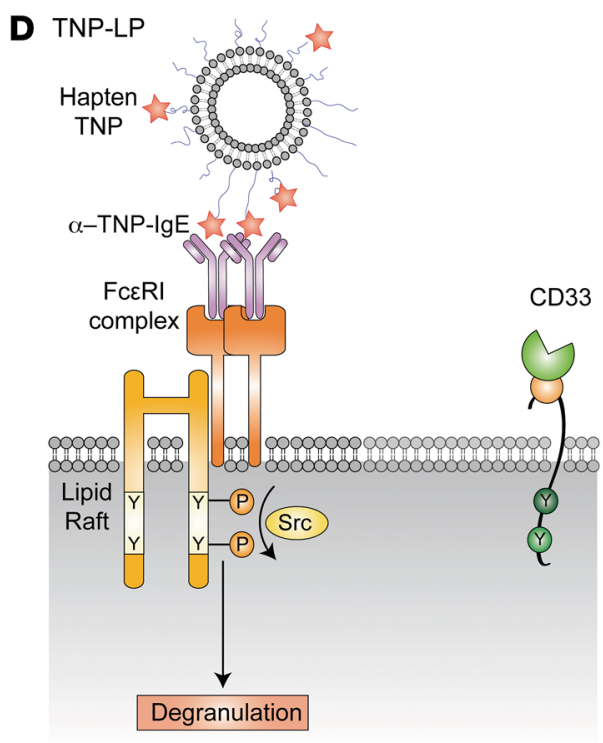

E

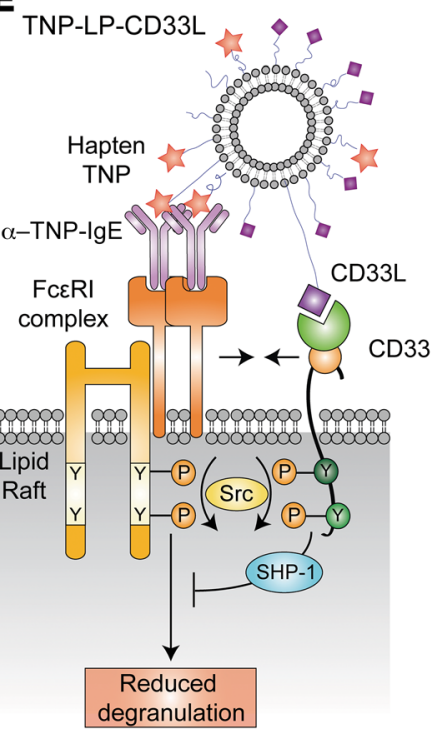

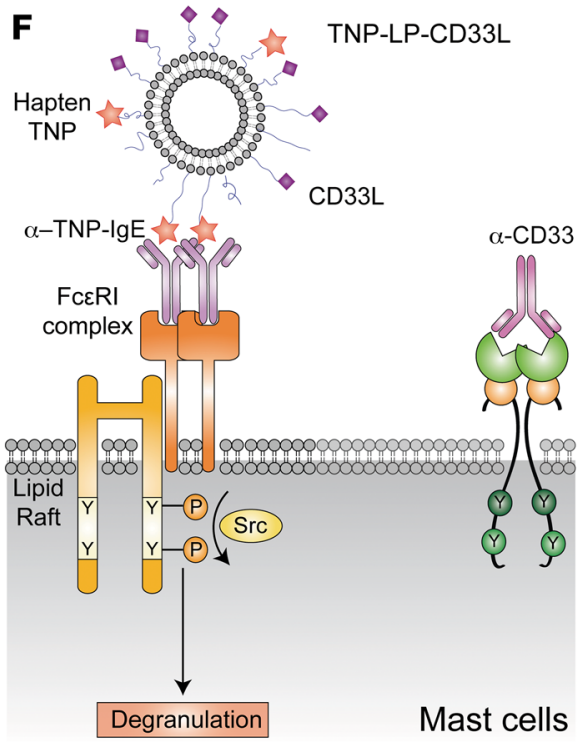

Figure 3. Recruitment of CD33 suppresses IgE/Fc\&RI signaling. (A) Phosphorylation of Syk, PLC 71 , MEK, and ERK in LAD2 cells after a 3-, 10-, or 30-minute stimulation using TNP-LP or TNP-LP-CD33L $(2 \mu \mathrm{M})$, as evaluated by Western blotting. (B) Phosphorylation of Syk and ERK in LAD2 cells after a 10-minute stimulation using TNP-LP, TNP-LP-CD33L, or LP-CD33L $(2 \mu \mathrm{M})$, as evaluated by Western blotting. (C) Phosphorylation of Syk, PLC $\gamma 1$, PLC 2, JNK, AKT, and ERK in CD33+ BMMCs cells after a 10-minute stimulation with TNP-LP, TNP-LP-CD33L, or LP-CD33L ( $2 \mu M$ ), as evaluated by Western blotting. (A-C) Total Syk and ERK were used as loading controls. (D-F) Proposed mechanisms of IgE/FceRI signaling induced by antigenic liposomes and recruitment of CD33 by CD33L. (D) TNP-LP stabilizes the anti-TNP-IgE-FcERI complex in lipid rafts with Src kinases that initiate the FceRI signaling cascade. We propose that CD33 has no basal impact on signaling, because it is not constitutively localized in the same microdomain with FcERI. (E) TNP-LP-CD33L recruits CD33 to the anti-TNP-IgE-Fc\&RI immunological synapse. Our results suggest that the cytoplasmic ITIMs of CD33 were phosphorylated by Src kinases and then recruited tyrosine phosphatases such as Shp-1, which dephosphorylated Syk, and other kinases.

(F) Proposed model showing that monoclonal anti-CD33 antibodies (or LP-CD33L) block recruitment of CD33 to the IgE-Fc\&RI complex and enable mast cell degranulation induced by TNP-LP-CD33L.

lenges with OVA-LP 5.5 hours later or $5 \mathrm{mg}$ OVA at 24 hours caused no anaphylaxis (Supplemental Figure 6D). The results demonstrate that treatment with antigenic liposomes with CD33L desensitizes mice to subsequent antigen challenge.

To determine whether the desensitization is antigen specific in vivo, mice sensitized with both anti-TNP-IgE and anti-OVA-IgE were treated with OVA-LP-CD33L, and after resting for 5.5 hours, the mice were challenged with either OVA-LP or TNP-LP (Figure $5 \mathrm{C})$. We observed that treatment with OVA-LP-CD33L produced no anaphylaxis (Figure 5D, left). Upon subsequent challenge with OVA-LP, the treated mice had no significant anaphylaxis relative to the untreated controls, whereas challenge with TNP-LP induced anaphylaxis in both the untreated and treated mice (Figure 5D, right). While the degree of anaphylaxis was milder in the treated mice, the difference was not statistically significant. These results suggest that desensitization caused by antigenic liposomes with CD33L is antigen specific.

To investigate the mechanism of desensitization, anti-TNPIgE-sensitized CD33-Tg mice were treated with $450 \mu \mathrm{g}$ TNP-LPCD33L or PBS. Six hours after treatment, peritoneal cells were collected and then incubated with fluorescent TNP-LP, and mast cells were analyzed by flow cytometry (Figure 5E). We observed that mast cell frequencies in the peritoneum were similar in PBSand TNP-LP-CD33L-treated mice (Figure 5F). TNP-LP strongly 

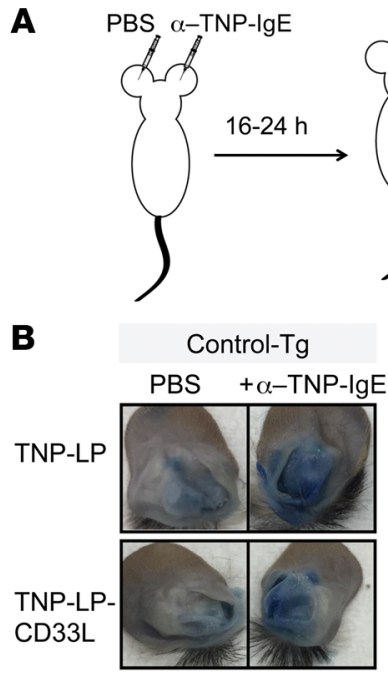

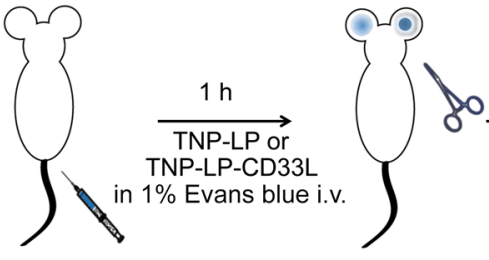

C OPBS $O+\alpha-T N P-\operatorname{lgE}$

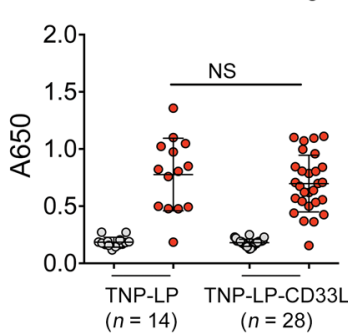

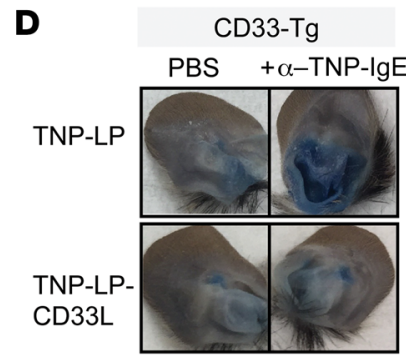

1. Cut ear into small pieces

2. Dissolve dye in $500 \mu \mathrm{l}$ of DMF

3. Measure A650

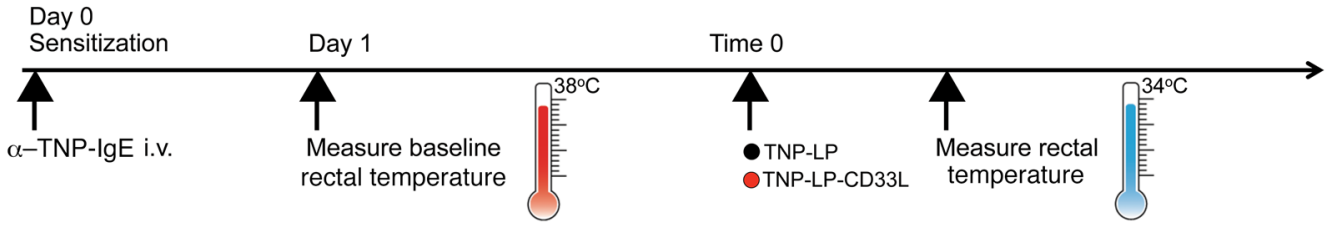

G

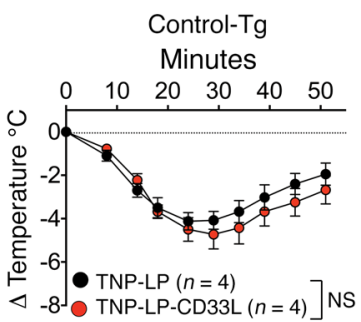

H

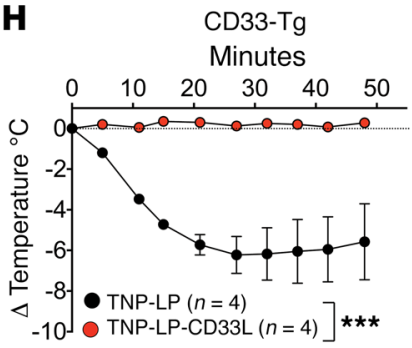

I

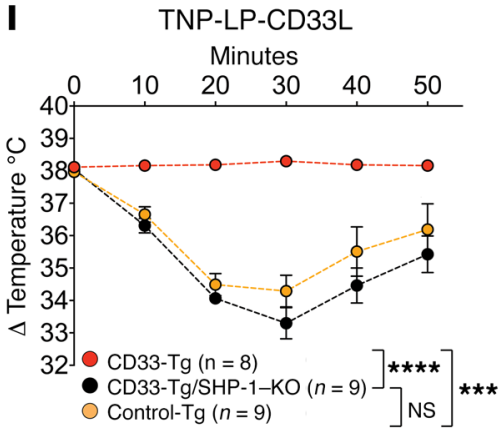

Figure 4. Suppression of IgE-mediated anaphylaxis. Display of CD33L on antigenic liposomes suppresses PCA and PSA in CD33-Tg mice (Mcpt5-Cre ${ }^{+/-}$

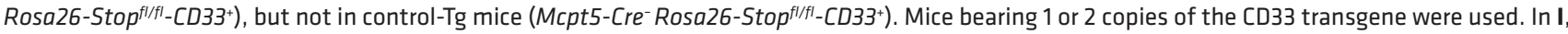
Mcpt5-Cre ${ }^{+/-}$mice expressing human CD33 (CD33-Tg) were crossed with Ptpn6f/ffl mice to yield mice with mast cells expressing CD33 and no Shp-1 (CD33-Tg/ Shp-1-KO). (A) Injection scheme for the PCA model. The genotypes of the mice were determined by PCR after the experiments. (B) Representative images of vascular leakage induced by TNP-LP or TNP-LP-CD33L $(50 \mu \mathrm{g})$ in control-Tg mice. (C) Quantification of local mast cell activation (absorbance at $650 \mathrm{~nm}$ ) induced by TNP-LP (50 $\mu \mathrm{g}, n=14)$ or TNP-LP-CD33L $(50 \mu \mathrm{g}, n=28)$ in control-Tg mice. (D) Representative images of vascular leakage induced by TNP-LP or TNP-LP-CD33L $(50 \mu \mathrm{g})$ in CD33-Tg mice. (E) Quantification of local mast cell activation (absorbance at $650 \mathrm{~nm}$ ) induced by TNP-LP (50 $\mu \mathrm{g}, n=21)$ or TNP-LP-CD33L (50 $\mu \mathrm{g}, n=27)$ in CD33-Tg mice. (F) Injection scheme for the PSA model. (G-I) Decrease in rectal temperature induced by TNP-LP or TNP-LPCD33L $(150 \mu \mathrm{g})$ in control-Tg mice (C), CD33-Tg mice (H), and CD33-Tg mice lacking Shp-1 (I) that were sensitized with $10 \mu \mathrm{g}$ anti-TNP-lgE. (G-I) Values are plotted as the mean \pm SEM at the indicated time points. Data are from 1 experiment ( $\mathbf{G}$ and $\mathbf{I})$ or were compiled from 3 (H) or 9 sets of experiments $(\mathbf{C}$ and E). ${ }^{* *} P<0.001$ and ${ }^{* * *} P<0.0001$, by 1-way ANOVA followed by Tukey's test (C and $\mathbf{E}$ ), repeated-measures (RM) 2-way ANOVA (G and $\mathbf{H}$ ), and RM 2-way ANOVA followed by Tukey's test (I).

bound to mast cells harvested from PBS-treated mice but did not bind significantly to mast cells harvested from TNP-LP-CD33Ltreated mice (Figure $5, \mathrm{G}$ and $\mathrm{H}$ ). The results are consistent with results for LAD2 cells (Supplemental Figure 3C), which showed that TNP-LP-CD33L either causes endocytosis of the anti-TNPIgE-FceRI complex $(32,33)$ or remains bound to the complex on the mast cell surface, blocking binding of TNP-LP.

Since mice are passively sensitized with anti-TNP-IgE intravenously in the PSA model, we reasoned that the antigenic liposomes (TNP-LP-CD33L) might also bind the serum anti-TNP-
IgE and alter its circulatory half-life. To assess this, we measured the serum levels of anti-TNP-IgE in PBS- and TNP-LP-CD33Ltreated animals over time. In the PBS-treated animals, the serum half-life of anti-TNP-IgE was 6 hours, which was consistent with the reported half-life of infused IgE (45). In contrast, TNP-LPCD33L accelerated the clearance of serum anti-TNP-IgE (Figure 5I). Thus, TNP-LP-CD33L has a direct impact on removing or blocking anti-TNP-IgE immobilized on mast cells and accelerates clearance of anti-TNP-IgE from the blood, precluding the resensitization of mast cells. 


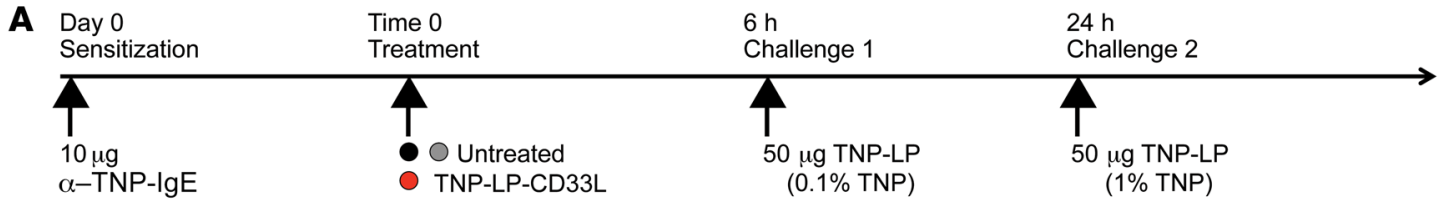

B

Day 1, time 0: treatement

Minutes

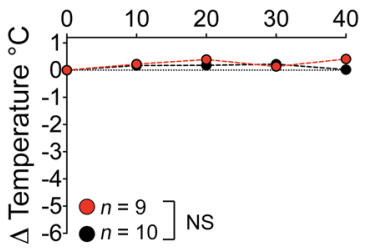

C

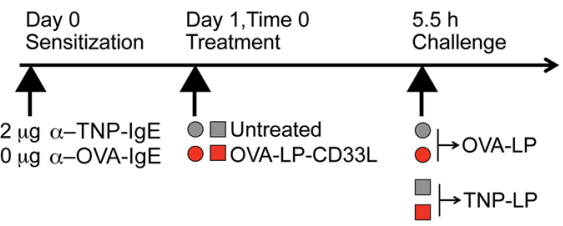

E

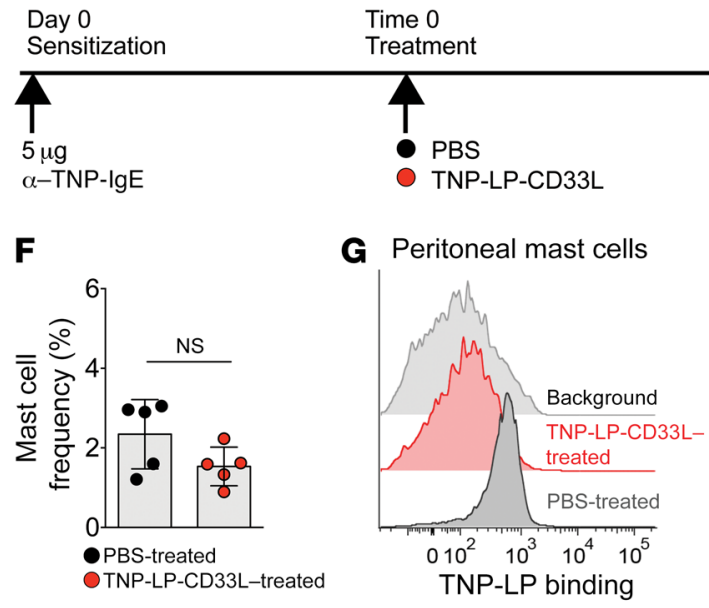

Day 1, $6 \mathrm{~h}$ after treatment: challenge 1

Minutes

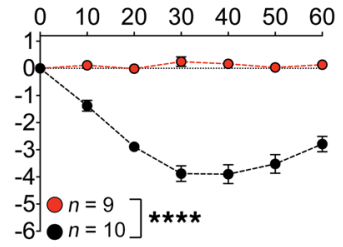

Day 2, $24 \mathrm{~h}$ after treatment: challenge 2

Minutes

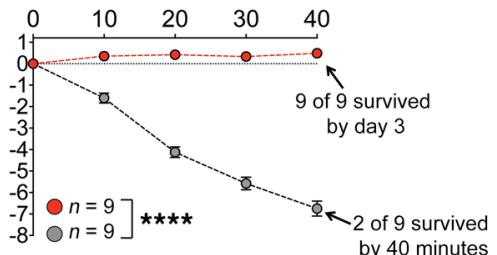

D

Day 1, time 0: treatment

Minutes

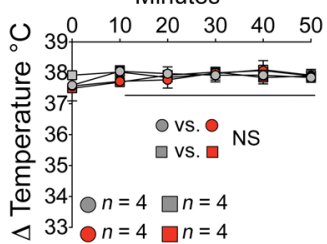

Day 1, $5.5 \mathrm{~h}$ after

treatment: challenge

Minutes

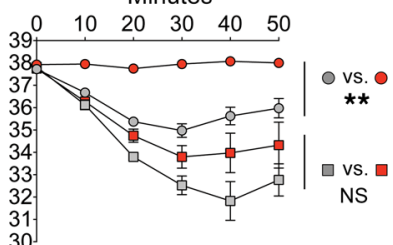

$6 \mathrm{~h}$

Euthanize mice

1. Harvest peritoneal cells

2. In vitro binding using fluorescent TNP-LP
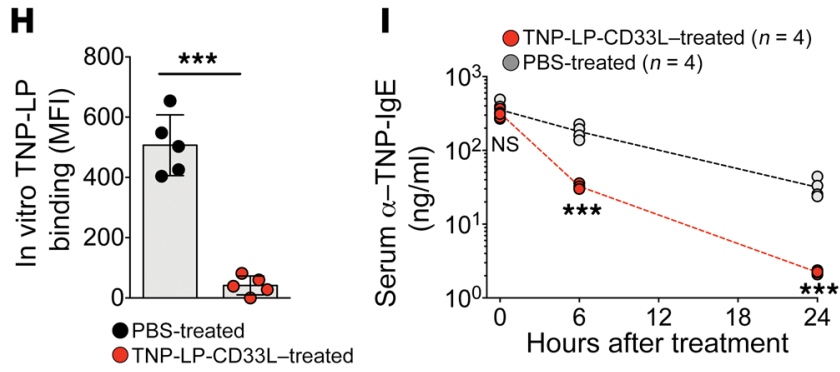

Figure 5. Antigenic liposomes with CD33L desensitize CD33-Tg mice to antigen challenge. (A) Injection scheme for desensitization to TNP. CD33-Tg mice were used in the TNP-LP-CD33L-treated group (red). Both CD33-Tg and control-Tg mice were used in the 2 untreated groups (black, gray). (B) Changes in rectal temperature induced by treatment or the challenges indicated in A. (C) Injection scheme to determine antigen specificity of desensitization. CD33-Tg mice were used in the OVA-LP-CD33L-treated group (red circles and squares). Both CD33-Tg and control-Tg mice were used in the untreated group (gray circles and squares). (D) Rectal temperature induced by the treatment or challenge illustrated in C. (B and D) Values are plotted as the mean \pm SEM. (E) Injection scheme used to evaluate the impact of TNP-LP-CD33L on mast cell frequency and anti-TNP-IgE on mast cells. Control mice received $200 \mu \mathrm{I}$ PBS. (F) Frequencies of mast cells from peritoneal fluid from mice treated in $\mathbf{E}$. Mast cell frequencies were determined by c- $\mathrm{Kit}^{+} \mathrm{CD} 45^{+} \mathrm{PI}^{-}$cells. (G) In vitro binding of fluorescent TNP-LP $(20 \mu \mathrm{M})$ to peritoneal mast cells harvested from mice treated as illustrated in C. (H) MFI of fluorescent TNP-LP binding to peritoneal mast cells quantified in $\mathbf{G}$. The background was determined using untreated cells from a naive mouse. (I) Serum anti-TNP-IgE quantified prior to and 6 hours and 24 hours after treatment with TNP-LP-CD33L $(450 \mu \mathrm{g})$ using CD33-Tg mice sensitized with $10 \mu \mathrm{g}$ anti-TNP-IgE. Control mice received $200 \mu \mathrm{l}$ PBS. Data in B were compiled from 2 experiments. Data are representative of $2(\mathbf{F}-\mathbf{H})$ or $3(\mathbf{I})$ independent experiments. ${ }^{* *} P<0.01,{ }^{* * *} P<0.001$, and ${ }^{* * * *} P<0.0001$, by RM 2-way ANOVA (B), RM 2-way ANOVA followed by Tukey's test (D), and unpaired, 2-tailed Student's $t$ test (F-I).

CD33 is expressed on human skin and lung mast cells and inhibits IgE-mediated airway bronchoconstriction. In view of the potent activity of CD33 in the suppression of mast cell activation in the murine models, we sought to extend the relevance to human mast cells. CD33 expression has been previously demonstrated on cul- tured human $\mathrm{CD}_{34}{ }^{+}$or cord blood-derived mast cells $(23,46)$, gastrointestinal mast cells (47), healthy/neoplastic bone marrow mast cells, and lung mast cells $(22,48)$. We performed flow cytometry to evaluate the expression of CD33 and other Siglecs on human mast cells isolated from surgically derived samples of discarded 
A

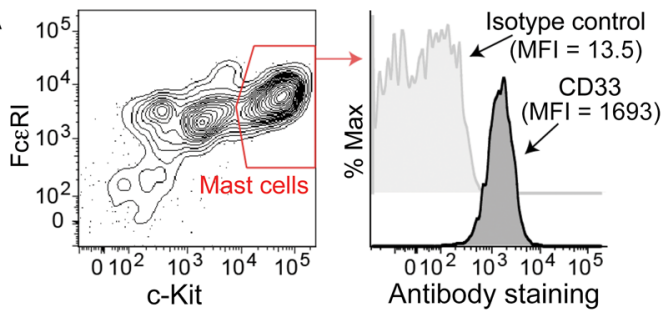

B

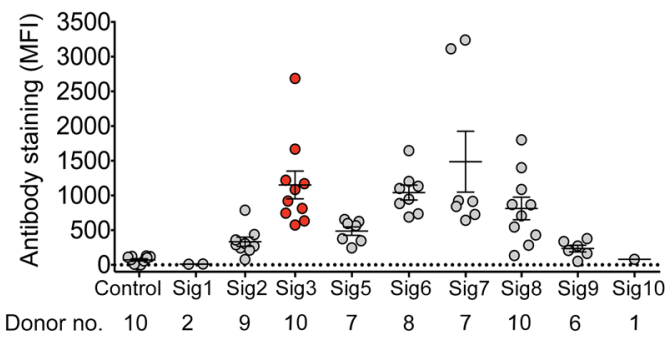

C

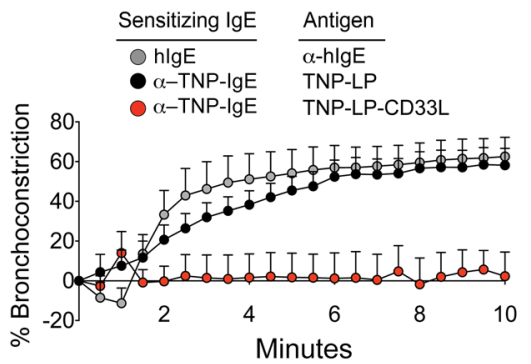

D

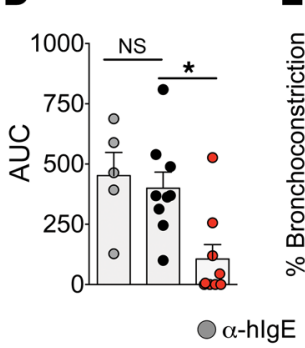

E

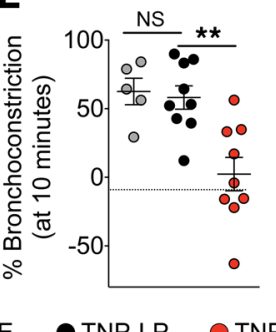

$\mathbf{F}$

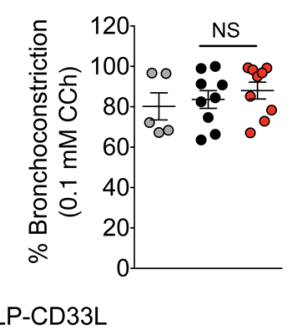

Figure 6. CD33 is expressed on human mast cells and inhibits IgE-mediated human airway bronchoconstriction. (A) Flow cytometric analysis of mast cells isolated from discarded human skin (c-Kithi FceRI+ gated on $\mathrm{PI}^{-}$CD45+CD3-CD19-CD56- cells) (left) and overlay of isotype control and anti-CD33 staining of gated mast cells (right). (B) MFI of antibody staining of Siglecs on mast cells isolated from skin that was discarded following surgical procedures ( $n=1$ to 10 donors). (C) Time course of the percentage of bronchoconstriction of hPCLSs. Lung slices were sensitized with human IgE (4 mg/ml, gray) or anti-TNP-IgE (10 $\mu \mathrm{g} / \mathrm{ml}$, black and red) with recombinant human SCF (200 $\mathrm{ng} / \mathrm{ml}$, R\&D Systems) overnight. Slices were challenged with anti-human IgE (20 $\mu \mathrm{g} / \mathrm{ml}$, gray), TNP-LP (50 $\mu \mathrm{M}$, black), or TNP-LP-CD33L (50 $\mu \mathrm{M}$, red) over a 10-minute period. The airway luminal area over time was compared with the baseline luminal area and expressed as the percentage of bronchoconstriction. Values represent the mean \pm SEM. (D) AUC induced by the indicated treatments. AUC values below 0 are plotted as 0 . (E) Percentage of bronchoconstriction induced by the indicated agents at 10 minutes. (F) Following stimulation with the indicated reagents, the percentage of bronchoconstriction induced by CCh (0.1 mM) was measured. ${ }^{*} P<0.05$ and ${ }^{*} P<0.01$, by 1-way ANOVA followed by Tukey's test (D-F). Gating of skin mast cells in $\mathbf{A}$ is representative of the 10 donors. Data in $\mathbf{C}-\mathbf{F}$ were compiled from 5 or 9 lung slices from 2 donors.

human breast, foreskin, facial, and abdominal skin from 10 individuals. Consistently high expression levels of CD33 and Siglec-6, -7 , and -8 were detected on human skin and low levels of CD22 and Siglec-5 in skin from all samples (Figure 6, A and B).

We next assessed whether endogenous CD33 expression levels were sufficient for TNP-LP-CD33L to inhibit IgE-FceRIdependent mast cell-mediated bronchoconstriction in human precision-cut lung slices (hPCLSs) ex vivo (49). As a positive control, we found that anti-IgE induced strong bronchoconstriction of slices sensitized with human IgE, and TNP-LP induced similar levels of bronchoconstriction in slices sensitized with anti-TNPIgE. Strikingly, TNP-LP-CD33L suppressed bronchoconstriction to baseline levels (Figure 6, C-E) but had no effect on bronchoconstriction induced by subsequent addition of carbachol (CCh) (Figure 6F), demonstrating that the tissues remained capable of constriction. Collectively, these data demonstrate that endogenous levels of CD33 are sufficient to inhibit IgE-dependent activation of lung mast cells.

\section{Discussion}

Mast cells play a central role in IgE-mediated allergic responses $(5,7-9,15)$, leading to life-threatening anaphylaxis in $2 \%$ to $5 \%$ of the US population in their lifetime $(3,4)$. Currently, there are no approved drugs that directly target mast cells for desensitization of allergic responses. A temporary acute method of desensitization called rapid desensitization is used for patients with allergies to life-saving medicines and involves a gradual increase in allergen doses over 3 to 4 hours to achieve a therapeutic dose (50). Allergen immunotherapy is used to induce prolonged antigen unresponsiveness and involves weekly subcutaneous or sublingual administration of allergen under medical supervision to monitor signs of anaphylaxis, with a slow increase of the dose to a plateau level that is continued for several years. The goal is to attain unresponsiveness to antigen by inducing Tregs and/or anti-allergen $\operatorname{IgG}_{4}$ to sequester antigen (12). For standard allergen immunotherapy, the prolonged treatment regimen under medical supervision for anaphylaxis is accompanied by poor patient compliance, and sensitivity often returns after the regular dosing of antigen ends (12). Reducing serum IgE levels with omaluzimab shows promise for accelerating the dose escalation in allergen immunotherapy $(51,52)$. One strategy to reduce the risk of anaphylaxis during allergen immunotherapy is to introduce allergens under the cover of small-molecule inhibitors targeting kinases involved in FceRI signaling (53-56). However, it remains to be seen whether kinase inhibitors are as efficacious and well tolerated in the primary treatment of allergies (14).

Here, we show that liposomes displaying both allergen and ligands for CD33 prevent the activation of IgE-sensitized mast cells and desensitize them to subsequent activation, while at the same time accelerating the clearance of circulating anti-allergen $\operatorname{IgE}$ and thus preventing resensitization. The result is a complete protection from anaphylaxis upon subsequent allergen challenge over several days. The direct effect on mast cells results from recruitment of CD33 to the IgE-FceRI complex comprising 
the microdomain with activated Src kinases, resulting in a profound suppression of downstream signaling pathways that result in degranulation and cytokine expression. Ligation of CD33 with 3 different clones of anti-CD33 or with liposomes containing CD33L alone has no effect on the degranulation of cytokine expression, underscoring the importance of CD33L being codisplayed with allergen on the liposome for recruitment of CD33 to the receptor complex. In addition to suppressing signaling by the antigen codisplayed on the liposome, the mast cells are desensitized to subsequent antigen exposure. One possible mechanism was that the IgE-FceRI- $\alpha$ chain was shed from the cell surface (57). Using LAD2 cells sensitized with AF555-labeled anti-TNP-IgE, we observed that TNP-LP or TNP-LP-CD33L (AF647) strongly bound to the LAD2 cells (Supplemental Figure 7, A and B) but did not decrease the AF555 signal detected from these cells (Supplemental Figure 7, C and D). Therefore, we attribute the lack of antigen responsiveness to endocytosis of the IgE-FceRI complex $(32,33)$, blockage of antigen binding to residual anti-allergen IgE on the mast cell surface, or a combination of both.

The in vitro desensitization using LAD2 cells was predominantly antigen specific, while the in vivo desensitization was antigen specific. The discrepancy could be due to the amount of antigen-specific IgE per mast cell (33). LAD2 cells were cultured in the absence of IgEs, hence its FceRI receptors were unoccupied. Therefore, anti-TNP-IgE (AF555) was able to label LAD2 cells in vitro (Supplemental Figure 7, C and D). By contrast, FceRIs from peritoneal mast cells are already occupied with endogenous IgEs, and we were unable to directly detect anti-TNP-IgE (AF555, $5 \mu \mathrm{g}$ ) labeling of peritoneal mast cells when it was injected intravenously (data not shown).

Since mast cells are not depleted by these antigenic liposomes, it is presumed that they will eventually generate new FceRI receptors and could be resensitized. However, because the antigenic liposomes also accelerate clearance of the antigen-specific IgE, there is no antibody in circulation for resensitizing the cells, and this accounts at least in part for the prolonged period of desensitization, lasting 2-3 days, particularly in this passively sensitized model, in which there is no replacement of the depleted antibody. It will be of interest to determine how long it takes for mast cells to become resensitized in immunized animals that will replace depleted IgE over time. In this regard, an anti-IgE analogous to omaluzimab (Xolair) could be used to deplete newly synthesized IgE to prevent resensitization.

Although human CD33 is abundantly expressed on most myeloid cells, including monocytes, DCs, eosinophils, macrophages, mast cells, and basophils, its role in the regulation of cell signaling is poorly understood (58). In a recent report evaluating the role of CD33 in myeloid cells of mice with a humanized immune system, genetic ablation of human CD33 was found to have minimal impact on innate immune functions (59). However, we show here that the inhibitory function of CD33 is highly context dependent. Expression of human CD33 in mast cells from CD33$\mathrm{Tg}$ mice did not alter mast cell survival or the degree of anaphylaxis relative to control-Tg mice. Moreover, ligation of CD33 with antiCD33 antibodies or liposomes with CD33L has little or no effect on allergen-induced mast cell activation. However, when CD33 is ligated to the IgE-FceRI receptor complex, it potently suppresses
FceRI signaling. Thus, for basophils that express both CD33 and the FceRI receptor, we would expect antigenic liposomes with CD33L to suppress IgE-mediated activation and degranulation to a degree equivalent to that seen with mast cells. However, for other myeloid cells that express CD33, we reason that antigenic liposomes with CD33L would have little impact, since, in the absence of an IgE-FceRI receptor complex that recognizes the antigen, they would effectively be "seen" as liposomes that contain ligand only, which we found to have no inhibitory effect on mast cells.

Previous efforts to exploit inhibitory receptors for the suppression of IgE-mediated mast cell activation have involved the use of chimeric proteins to recruit inhibitory receptors to the IgE-FceRI complex $(14,15)$. One general approach uses bispecific antibodies that ligate either IgE or the FceRI and an inhibitory receptor (e.g., Fc $\gamma$ RIIb or CD300a) (16-19). Here, the objective was to constitutively suppress the mast cell response by coupling the inhibitory receptor to the IgE-FceRI complex. Another approach is to couple an allergen (e.g., cat allergen Fel d 1, peanut allergen Ara h 2, or TNP) to an antibody fragment or antibody that binds to an inhibitory receptor (e.g., Fc $\gamma$ RIIb or allergin-1) (20, 21, 60). Although some of these constructs have shown promise in murine models, translation to humans would require uniform expression of the inhibitor on the targeted cells and limited expression on other cell types that could be the basis for off-target effects. In this regard, the Fc $\gamma$ RIIb receptor is expressed on human intestinal mast cells but not on skin mast cells (61), and, conversely, the CD300a receptor is widely expressed on both myeloid and lymphoid cells (62). Therefore, the biodistribution of these novel biotherapeutics should be carefully studied.

In addition to CD33, human mast cells also express several other ITIM-containing Siglecs, including Siglec-6, -7, -8, and -9 (Figure 6B). Evidence to date suggests that other members of the Siglec family can also regulate mast cell responses. Indeed, antibody-mediated cross-linking of Siglec-7 and Siglec-9 to FceRI has been shown to suppress IgE-mediated mast cell degranulation $(63,64)$. Likewise, antibody-mediated ligation of Siglec- 8 or antibody-mediated ligation of Siglec- 8 to the FceRI receptor suppressed FceRI-mediated calcium flux and mast cell degranulation (65). Thus, in principle, ligands for other Siglecs could substitute for CD33L in the antigenic liposomal nanoparticle platform for the suppression of mast cell-mediated anaphylaxis, making the family of Siglecs attractive targets for the development of therapeutics to treat allergies.

\section{Methods}

Mice. All mice were on a C57BL/6 genetic background. Rosa26-Stop ${ }^{f / t_{-}}$ CD33 mice were generated by subcloning cDNA encoding full-length CD33 (OriGene, catalog SC122608, sequence identical to that of GenBank BC028152.1) into the AscI site of a CTV targeting vector (Addgene, plasmid 15912). Electroporation of the targeting construct into PRX ES cells (C57BL/6N background), blastocyst injections, and chimera breeding with C57BL/6J albino mice (The Jackson Laboratory, stock no. 000058) were performed according to standard protocols (66). Insertion of the targeted vector into the Rosa26 locus was confirmed by Southern blot analysis of ES cells as previously described (34). The Rosa26-Stop $p^{f / f l}-C D 33$ mice were genotyped by PCR using digested tail samples. A common forward primer located 
in the $5^{\prime}$ homology region (5'-GAGCTGCAGTGGAGTAGGCG-3') was used. The WT Rosa26 locus was identified using a reverse primer (5'-TGCTGCATAAAACCCCAGAT-3'), with a band of $370 \mathrm{bp}$. Tg mice were detected using a reverse primer located in the CAG promoter (5'-GGGCGTACTTGGCATATGAT-3'), with a band of $566 \mathrm{bp}$. Mcpt5-Cre mice were genotyped by PCR (5'-ACAGTGGTATTCCCGGGGAGTGT-3' and 5'-GTCAGTGCGTTCAAAGGCCA-3') as previously described (67). C57BL/6J mice were ordered from the Scripps Rodent Breeding colony. Ptpn $6^{f / f l}$ mice (stock no. 008336) were genotyped by PCR according to The Jackson Laboratory's protocol.

Antigen and sugar-lipid conjugation. The high-affinity human CD33 ligand CD33L was attached to PEG-DSPE by coupling the C5- and C9-modified trisaccharide to NHS-PEG ${ }_{2000}$-DSPE (NOF) using the conditions illustrated in Supplemental Figure 1A (30). TNP-PEG-DSPE was synthesized by coupling TNP- $\varepsilon$-aminocaproyl-OSu (T-1030, Biosearch Technology) to NHS-PEG 2000 -DSPE as illustrated in Supplemental Figure 1B. OVA and Ah2 were coupled to $P_{E G}{ }_{2000}-D S P E$ as previously described $(26,28,29)$.

Liposomes. All liposomes were composed of a 57:38:5 molar ratio of distearoyl phosphatidylcholine (DSPC) (Avanti Polar Lipids), cholesterol (Sigma-Aldrich), and polyethylene glycol-distearoyl phosphoethanolamine ( $\mathrm{PEG}_{2000}$-DSPE, NOF; PEG-DSPE). When antigen-PEGDSPE or CD33L-PEG-DSPE is included in the formulation, there is a proportionate reduction in PEG-DSPE, such that PEG-DSPE is kept at $5 \%$ of the total volume. To make TNP-LP, $0.1 \%, 0.4 \%$, or $1 \%$ of TNPPEG-DSPE was added to the lipid mixture. To make LP-CD33L, 3\% CD33L-PEG-DSPE was added to the lipid mixture. To copresent TNP and CD33L (TNP-LP-CD33L) on the same liposomes, both TNP-PEGDSPE $(0.1 \%$ or $0.4 \%)$ and CD33L-PEG-DSPE (3\%) were added to the lipid mixture. To make fluorescently labeled liposomes, 0.1\% AF647PEG-DSPE or AF488-PEG-DSPE was added to the lipid mixture.

To assemble the liposomes, DSPC, cholesterol, and PEG-DSPE (dissolved in chloroform) were mixed, evaporated with nitrogen, and suspended in $200 \mu \mathrm{l}$ DMSO. TNP-PEG-DSPE and/or CD33LPEG-DSPE (DMSO stocks, stored at $-20^{\circ} \mathrm{C}$ ) were then added and lyophilized. The dried lipids were hydrated with PBS. For OVA-LP and Ah2-LP, OVA-PEG-DSPE and Ah2-PEG-DSPE were added to PBS-hydrated lipids. The mixtures were then sonicated for $5 \times 30$ seconds. Liposomes were passed through 800-nm, 200-nm, and 100-nm controlled pore membranes (Nuclepore, Sigma-Aldrich) 20 times per membrane using an extruder (Avanti Polar Lipids, 610023) at room temperature (RT). Liposomes were stored at $4^{\circ} \mathrm{C}$ to $7^{\circ} \mathrm{C}$ in the dark for up to 6 months.

For in vitro experiments, the quantity of liposomes used was based on the final concentration of total molar lipids of liposomes. Liposomes containing 0.1\% TNP-PEG-DSPE with or without $3 \%$ CD33L-PEG-DSPE were used in Figure 1, D and F; Figures 3-6; Supplemental Figure 3; and Supplemental Figures 5-7. Liposomes containing 0.4\% TNP-PEG-DSPE with or without 3\% CD33L-PEG-DSPE were used in Figure 1, E, G, and H; Figure 2, F-J; and Supplemental Figure 2. Liposomes containing 3\% CD33L-PEG-DSPE with or without 0.1\% AF647-PEG-DSPE were used in Figure 1, C, F, and G; Figure 2, E and G; Figure 3, B and C; Supplemental Figure 1; and Supplemental Figure 3C, and Supplemental Figure 4, G and H. Liposomes containing 0.1\% Ah2-PEG-DSPE with or without 3\% CD33-PEG-DSPE were used in Figure 1I. Liposomes containing 0.1\% OVA-PEG-DSPE with or without $3 \%$ CD33-PEG-DSPE, with or without $0.1 \%$ AF647-
PEG-DSPE, were used in Figure 1J; Figure 5D; Supplemental Figure 2D; Supplemental Figure 3C; and Supplemental Figure 6D. Liposomes containing 1\% TNP-PEG-DSPE were used in Figure 5B and Supplemental Figure 6B.

LAD2 and BMMC cell culture. The human LAD2 mast cell line (from Arnold Kirshenbaum, National Institute of Allergy and Infectious Diseases [NIAID], NIH) was cultured using StemPro-34 SFM (Gibco, Thermo Fisher Scientific) supplemented with $2 \mathrm{mM}$ L-glutamine, $100 \mathrm{U} / \mathrm{ml}$ penicillin, $100 \mu \mathrm{g} / \mathrm{ml}$ streptomycin, $10 \mathrm{mM}$ HEPES, and $50 \mu \mathrm{M} \beta$-mercaptoethanol (37). To culture BMMCs, femurs from CD33-Tg mice were flushed with RPMI-1640 and cultured in media (RPMI 1640, 10\% FBS, 2 mM L-glutamine, $100 \mathrm{U} / \mathrm{ml}$ penicillin, 100 $\mu \mathrm{g} / \mathrm{ml}$ streptomycin, $10 \mathrm{mM}$ HEPES, and $50 \mu \mathrm{M} \beta$-mercaptoethanol) supplemented with IL-3-conditioned media harvested from WEHI-3B cells for 3 to 4 weeks (37). Maturation of BMMCs was determined by flow cytometry using c-Kit and FceRI double-positive staining. For in vitro assays, $\mathrm{GFP}^{+} \mathrm{BMMCs}$ were sorted busing a FACSAria (BD Biosciences), and sorted cells were expanded in IL-3-conditioned media. All BMMCs were used within 6 weeks of culturing.

Human CD33 CHO cells. Full-length human CD33 was amplified from cDNA (OriGene, catalog SC122608) and subcloned into a pcDNA5/FRT/V5-His vector using the Nhe I and Age I site. The $\mathrm{R}(\mathrm{CGG}) 119$ A (GCG) mutation in the variable region of CD33 was obtained using primers (5'-ATACTTCTTTGCGATGGAGAGAGGAAG-3') and (5'-GAACCATTATCCCTCCTC-3') and standard cloning techniques (Q5 mutagenesis, New England BioLabs). Flp-in CHO cells (Invitrogen, Thermo Fisher Scientific) were then transfected with WT or R119A CD33 containing the pcDNA5/FRT/V5-His vector with pOG44 using Lipofectamine 2000 (Invitrogen, Thermo Fisher Scientific), selected with hygromycin B (500 $\mu \mathrm{g} / \mathrm{ml}$, Roche), and cultured in DMEM-F12 (Gibco, Thermo Fisher Scientific) supplemented with $10 \% \mathrm{FBS}, 100 \mathrm{U} / \mathrm{ml}$ penicillin, and $100 \mu \mathrm{g} / \mathrm{ml}$ streptomycin.

Flow cytometry. All antibodies are listed in Supplemental Table 1. Cells $\left(<2 \times 10^{6}\right.$ cells/condition) were stained with antibody cocktails in FACS buffer (HBSS supplemented with 2 mM EDTA and 0.1\% BSA) on ice for at least 20 minutes in the dark. Cells were then washed with FACS buffer and suspended in FACS buffer containing $0.5 \mu \mathrm{g} / \mathrm{ml}$ propidium iodide (PI). All data were acquired using the BD LSR II (BD Biosciences) and analyzed with Flowjo software (version 9.3.3).

Liposome-binding assay. LAD2 cells, BMMCs, CHO cells $\left(5 \times 10^{4}\right.$ to $1 \times 10^{5}$ cells/condition), or peritoneal cells $\left(<2 \times 10^{6}\right.$ cells/mouse $)$ were incubated with the indicated liposomes $(20 \mu \mathrm{M}$ final liposome concentration, $37^{\circ} \mathrm{C}, 30-60 \mathrm{~min}$ ) in media (RPMI 1640 plus $10 \% \mathrm{FBS}$ ). Cells were washed, stained with antibodies in FACS buffer if needed, and analyzed using the BD LSR II. In Figure 1C and Supplemental Figure $1, \mathrm{G}$ and $\mathrm{H}, \mathrm{LAD} 2$ cells were first treated with isotype control or antiCD33 antibody $\left(4 \mu \mathrm{g} / \mathrm{ml}\right.$ in $\left.50 \mu \mathrm{l} \mathrm{media,} 37^{\circ} \mathrm{C}, 60 \mathrm{~min}\right)$. Liposomes (40 $\mu \mathrm{M}$, in $50 \mu \mathrm{l}$ media) were then directly added to the cells in the presence of antibodies $\left(37^{\circ} \mathrm{C}, 60 \mathrm{~min}\right)$. In Supplemental Figure 3C, LAD2 cells sensitized with anti-TNP-IgE and anti-OVA-IgE (clones MEB38, PMP68, and EC1, each at $500 \mathrm{ng} / \mathrm{ml}$, overnight) were first incubated with TNP-LP, TNP-LP-CD33L, or LP-CD33L $\left(100 \mu \mathrm{l}, 20 \mu \mathrm{M}, 37^{\circ} \mathrm{C}, 60\right.$ $\mathrm{min}$ ), and TNP-LP and OVA-LP (AF488 or AF647 labeled, $100 \mu \mathrm{l}, 40$ $\mu \mathrm{M})$ were then directly added to the cells $\left(37^{\circ} \mathrm{C}, 30 \mathrm{~min}\right)$.

IgE. Murine anti-TNP-IgE (clone MEB38) was purchased from BioLegend. Murine anti-OVA-IgE (clone EC1) was purchased from Chondrex, and clone PMP68 was purchased from Bio-Rad. Human 
anti-OVA IgE (clone 11B6) was provided by Scott A. Smith (Vanderbilt University Medical Center, Nashville, Tennessee, USA).

Calcium flux. LAD2 cells, sensitized with anti-TNP-IgE $(1 \mu \mathrm{g} / \mathrm{ml}$, overnight), were washed with PBS and incubated in RPMI medium

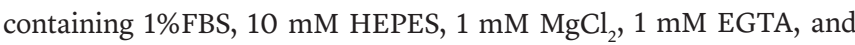
$1 \mu \mathrm{M}$ indo-1 (Invitrogen, Thermo Fisher Scientific) at $15 \times 10^{6}$ cells $/ \mathrm{ml}$ for 30 minutes in $37^{\circ} \mathrm{C}$ water bath. After incubation, cells were washed with the same buffer without indo- 1 and suspended in HBSS containing $1 \% \mathrm{FBS}, 1 \mathrm{mM} \mathrm{MgCl}_{2}$, and $1 \mathrm{mM} \mathrm{CaCl}_{2}$ at $2 \times 10^{6}$ cells $/ \mathrm{ml}$. Cells were stored on ice, and an aliquot $(400 \mu \mathrm{l})$ was warmed $\left(37^{\circ} \mathrm{C}, 5 \mathrm{~min}\right)$ prior to calcium flux initiation. Cells were stimulated with TNP-LP or TNPLP-CD33L at a final total liposome concentration of $2.5 \mu \mathrm{M}$, and indo-1 fluorescence (violet versus blue) was monitored by flow cytometry for 3 minutes at $37^{\circ} \mathrm{C}$. The addition of liposomes took place 10 seconds after starting the acquisition. Data were analyzed, and the AUC were calculated with FlowJo software (version 9.3.3) using the kinetics functions. The signal generated from cells that received $1 \mu \mathrm{PBS}$ was used to determine the level of background staining for the assay.

Degranulation. LAD2 cells ( $10^{4}$ cells/well) or sorted $\mathrm{GFP}^{+} \mathrm{BMMCs}$ $\left(3 \times 10^{4}\right.$ cells/well $)$ cultured from CD33-Tg mice were sensitized with anti-TNP-IgE ( $1 \mu \mathrm{g} / \mathrm{ml}$ in $100 \mu \mathrm{l}$ culture media overnight) in Figure 1, E-H; Figure 2, F and H; and Supplemental Figure 2, A-C. The next day, cells were washed and stimulated with the indicated liposomes in HEPES buffer (HBBS supplemented with $20 \mathrm{mM}$ HEPES, $0.2 \mathrm{mg} / \mathrm{ml}$ $\mathrm{CaCl}_{2}, 0.2 \mathrm{mg} / \mathrm{ml} \mathrm{MgSO}_{4}$, and $0.4 \mathrm{mg} / \mathrm{ml} \mathrm{BSA}$ ) for 30 to 60 minutes at $37^{\circ} \mathrm{C}$. Degranulation was measured as the release of $\beta$-hex, which was quantified by the digestion of its substrate 4-nitrophenyl- $N$ acetyle- $\beta$-glucosaminide (PNAG) $(0.35 \mathrm{mg} / \mathrm{ml}$ in PBS supplemented with $8 \mathrm{mg} / \mathrm{ml}$ sodium citrate, $0.35 \mathrm{mg} / \mathrm{ml}, \mathrm{pH} 4.5)$. The percentage of degranulation (percentage of $\beta$-hex) was determined by dividing the $\beta$-hex activity in the supernatant by that from the cell pellet (37). Cells receiving buffer only were used to determine the background for each experiment, which was less than $10 \%$.

In Figure 1F, $30 \mu \mathrm{M}$ TNP-LP and $30 \mu \mathrm{M}$ LP-CD33L were premixed in HEPES buffer and then directly added to the LAD2 cells. In Figure $1 \mathrm{G}$, the LAD2 cells were first treated with buffer or $20 \mu \mathrm{M}$ LP-CD33L (in $50 \mu \mathrm{l}, 37^{\circ} \mathrm{C}, 1 \mathrm{~h}$ ) and then stimulated with $50 \mu \mathrm{l} \mathrm{HEPES} \mathrm{buffer} \mathrm{con-}$ taining $60 \mu \mathrm{M}$ TNP-LP or TNP-LP-CD33L. In Figure 1H and Figure $2 \mathrm{H}$, cells were first treated with isotype control or anti-CD33 (WM53 at 2 or $4 \mu \mathrm{g} / \mathrm{ml}$, in $50 \mu \mathrm{l}, 37^{\circ} \mathrm{C}, 1 \mathrm{~h}$ ) and then stimulated with $50 \mu \mathrm{HEPES}$ buffer containing $60 \mu \mathrm{M}$ TNP-LP or TNP-LP-CD33L in the presence of the antibodies. In Figure 1I, LAD2 cells were sensitized with 1:5 diluted plasma from a peanut-allergic patient (Plasma Lab, patient no. 22132, final anti-peanut IgE $>20 \mathrm{kU} / \mathrm{l})$. In Figure 1J, LAD2 cells were sensitized with human anti-OVA-IgE (clone 11B6, $1 \mu \mathrm{g} / \mathrm{ml}$, overnight). In Supplemental Figure 3, A and B, LAD2 cells sensitized with antiTNP and anti-OVA-IgE were first treated with buffer containing $5 \mu \mathrm{M}$ TNP-LP-CD33L or buffer alone $\left(100 \mu \mathrm{l}, 37^{\circ} \mathrm{C}, 1 \mathrm{~h}\right)$ and then washed with $100 \mu \mathrm{l}$ HEPES buffer and stimulated with $\mathrm{TNP}^{31} \mathrm{BSA}$ (Biosearch) or OVA (Worthington, $100 \mu \mathrm{l}, 37^{\circ} \mathrm{C}, 1 \mathrm{~h}$ ). Degranulation induced by 5 $\mu \mathrm{M}$ TNP-LP-CD33L was determined by different aliquots of the cells run in parallel. In Supplemental Figure 2, A-C, LAD2 cells were treated with different clones of anti-CD33 antibodies at different concentrations (in $50 \mu \mathrm{l} \mathrm{HEPES} \mathrm{buffer,} 37^{\circ} \mathrm{C}, 1 \mathrm{~h}$ ). TNP-LP or TNP-LP-CD33L $(10 \mu \mathrm{M}$ in $50 \mu \mathrm{l}$ HEPES buffer) was then added to the cells in the presence of antibodies. In Supplemental Figure 2D, LAD2 cells sensitized with anti-OVA-IgE were first treated with antibodies $(4 \mu \mathrm{g} / \mathrm{ml}$ in 50 $\left.\mu \mathrm{l}, 37^{\circ} \mathrm{C}, 1 \mathrm{~h}\right)$. OVA-LP or OVA-LP-CD33L (60 $\mu \mathrm{M}$ in $\left.50 \mu \mathrm{l}\right)$ was then added to the cells in the presence of antibodies.

Peritoneal cells. After mice were euthanized by $\mathrm{CO}_{2}$ overdose, the outer skin was cut open and pulled back. The inner skin was gently lifted by forceps, and $5 \mathrm{ml}$ PBS was injected into the peritoneum using a 25-gauge needle. After gentle massages, the peritoneum was placed on top of a 50-ml tube. The inner skin was then cut open with scissors. Collected cells were transferred to $15-\mathrm{ml}$ tubes, pelleted $(300 \mathrm{~g}$, $5 \mathrm{~min}$ ), and counted by a hemocytometer. Dead cells were excluded by trypan blue (Gibco, Thermo Fisher Scientific). Mast cell numbers in Figure 2C were determined by multiplying the total number of cells by the percentages of cells that were $\mathrm{c}-\mathrm{Kit}^{+}$within the $\mathrm{PI}^{-} \mathrm{CD} 45^{+}$gate as determined by flow cytometry.

Cytokine ELISA. Cytokines were measured as previously described (37) with some modifications. BMMCs were sensitized overnight with $1 \mu \mathrm{g} / \mathrm{ml}$ anti-TNP-IgE in IL-3-conditioned media. The next day, the cells were washed and stimulated with the indicated reagents in culturing media without IL-3 for 5 to 6 hours at $37^{\circ} \mathrm{C}\left(10^{5}\right.$ cells $\left./ 100 \mu \mathrm{l}\right)$. After centrifugation (300 g, $5 \mathrm{~min}$ ), the supernatants were collected. TNF- $\alpha$, IL-4, IL-6 (BioLegend), and IL-13 (R\&D Systems) were measured by ELISA. All capturing and detection antibodies were used at 2 to $2.5 \mu \mathrm{g} / \mathrm{ml}$. All ELISAs were developed using TMB Peroxidase Substrate (75 $\mu \mathrm{l} /$ well; Rockland) and quenched with $2 \mathrm{M} \mathrm{H}_{2} \mathrm{SO}_{4}(75$ $\mu \mathrm{l} /$ well), and A450 was measured using a plate reader (Synergy H1, BioTek). In Figure 2, I and J, BMMCs were first incubated with isotype control or anti-CD33 $\left(10 \mu \mathrm{g} / \mathrm{ml}, 37^{\circ} \mathrm{C}, 1 \mathrm{~h}\right)$. TNP-LP or TNP-LPCD33 (final total liposome concentration at $40 \mu \mathrm{M}$ ) was added to the BMMCs in the presence of antibodies and then incubated $\left(37^{\circ} \mathrm{C}, 5 \mathrm{~h}\right)$.

Western blot analysis. LAD2 cells or sorted $\mathrm{GFP}^{+}$BMMCs cultured from $\mathrm{CD} 33-\mathrm{Tg}$ mice were sensitized overnight in culturing media containing $1 \mu \mathrm{g} / \mathrm{ml}$ anti-TNP-IgE. LAD2 cells or BMMCs $\left(3 \times 10^{6}\right.$ cells/condition) were washed and then stimulated with the indicated reagents (final liposome concentration of $2 \mu \mathrm{M}$ in $500 \mu \mathrm{l}$ culture media at $37^{\circ} \mathrm{C}$ ) using culture media. Cells were quenched with $4^{\circ} \mathrm{C}$ PBS, pelleted $(15,800 \mathrm{~g}, 13 \mathrm{~s})$, and lysed $\left(4^{\circ} \mathrm{C}, 30 \mathrm{~min}\right)$ in $160 \mu$ lysis buffer (9803S, Cell Signaling Technology). Cell debris was removed by centrifugation $\left(15,800 \mathrm{~g}, 10 \mathrm{~min}, 4^{\circ} \mathrm{C}\right)$. LDS Sample Buffer (50 $\mu \mathrm{l} /$ sample; Bolt) and DTT ( $20 \mu \mathrm{l} /$ sample, $2.5 \mathrm{M}$ ) were added to the cleared lysate $(150 \mu \mathrm{l} \mathrm{each})$ and denatured $\left(90^{\circ} \mathrm{C}, 10 \mathrm{~min}\right)$. Whole-cell lysates (5-10 $\mu \mathrm{l} /$ lane) were run on $4 \%$ to $12 \%$ Bis-Tris Gels (Invitrogen, Thermo Fisher Scientific; 150 Volts, $90 \mathrm{~min}$ ) and transferred onto a nitrocellulose membrane. Antibodies are listed in Supplemental Table 2. Amersham ECL detection reagent and Hyperfilm (GE Healthcare) were used to develop the images.

$P C A$. One ear was given $25 \mu \mathrm{l}$ PBS as a mock injection, and the other ear was given $125 \mathrm{ng}$ anti-TNP-IgE (in $25 \mu \mathrm{lPBS}$ ) intradermally using insulin syringes (29G1/2, U-100, Comfort Point). The next day, $50 \mu \mathrm{g}$ TNP-LP or TNP-LP-CD33L ( $200 \mu \mathrm{l}$ of $0.33 \mathrm{mM}$ liposomes) was delivered via the lateral tail vein in PBS containing 1\% Evans blue dye (w/v, Chem-Impex). All mice were euthanized 60 minutes after injection. Ears were excised in small pieces, dissolved in $500 \mu \mathrm{l}$ dimethylformamide (DMF), and shaken $(>500 \mathrm{rpm})$ overnight at $37^{\circ} \mathrm{C}$. A constant volume of $200 \mu \mathrm{l}$ cleared DMF was used to measure Evans blue dye incorporation, and A650 was measured using a Synergy H1 plate reader (BioTek Instruments).

PSA. Mice were sensitized with anti-TNP or anti-OVA-IgE through tail-vein injections. The next day, after baseline rectal temperatures 
were measured, the indicated liposome (in $200 \mu \mathrm{l}$ PBS/mouse) was injected via the tail vein, and systemic anaphylaxis was quantified by measuring the decrease in rectal temperature (RET-3 and BAT-12, PhysiTemp Instruments).

Dose of IgE. In Figure 4, G-I; Figure 5, B and I; Supplemental Figure 5, A, C, and D; and Supplemental Figure 6B, mice were sensitized with $10 \mu \mathrm{g}$ anti-NP-IgE. In Figure 5D, mice were sensitized with $2 \mu \mathrm{g}$ anti-TNP-IgE and $10 \mu \mathrm{g}$ anti-OVA-IgE ( $5 \mu \mathrm{g}$ EC1 and $5 \mu \mathrm{g}$ PMP68). In Figure 5, E-H, mice were sensitized with $5 \mu \mathrm{g}$ anti-TNP-IgE. In Supplemental Figure 5E, mice were sensitized with $2 \mu \mathrm{g}$ anti-TNP-IgE. In Supplemental Figure 6D, mice were sensitized with $20 \mu \mathrm{g}$ anti-OVAIgE (10 $\mu \mathrm{g}$ EC1 and $10 \mu \mathrm{g}$ PMP68).

Liposome dose. In Figure 4, G-I, and Supplemental Figure 5E, mice were given $150 \mu \mathrm{g}$ TNP-LP or TNP-LP-CD33L (200 $\mu \mathrm{l}$ of $1 \mathrm{mM}$ liposome). In Figure 5, B and F-I, mice were treated with $450 \mu \mathrm{g}$ TNPLP-CD33L (200 $\mu$ l of $3 \mathrm{mM})$. In Supplemental Figure 6B, mice were treated with 1 or 2 injections of TNP-LP-CD33L $(200 \mu \mathrm{l}$ of $1.25 \mathrm{mM}$ liposomes each). In Figure 5B and Supplemental Figure 6B, mice were challenged with $50 \mu \mathrm{g}$ of 0.1\%TNP-LP and/or $50 \mu \mathrm{g}$ 1\%TNP-LP (200 $\mu \mathrm{l}$ of $0.33 \mathrm{mM}$ liposomes). In Figure 5C and Supplemental Figure 6D, mice were given $159 \mu \mathrm{g}$ OVA-LP or OVA-LP-CD33L $(200 \mu \mathrm{l}$ of $1 \mathrm{mM}$ liposomes containing $150 \mu \mathrm{g}$ lipid and $9 \mu \mathrm{g}$ OVA-PEG-DSPE) or $150 \mu \mathrm{g}$ TNP-LP (200 $\mu \mathrm{l}$ of $1 \mathrm{mM}$ liposomes).

Quantification of circulating anti-TNP-IgE. The amount of antiTNP-IgE in the serum was determined by ELISA. Microplates (Greiner Bio-One, 655081) were coated with TNP ${ }^{31}$ BSA (Biosearch Technology, $10 \mu \mathrm{g} / \mathrm{ml}$ in $50 \mu \mathrm{l} \mathrm{PBS} /$ well, overnight). The next day, the plates were washed 5 times with PBS-T (PBS containing 0.05\% Tween-20, v/v), blocked with PBS containing $1 \%$ BSA (w/v, >2 h, RT), and then washed 5 times with PBS-T. Mice were bled prior to treatment and 6 and 24 hours after treatment. Serially diluted serum (diluted at 1:5, 1:15, and 1:45 in PBS containing $1 \%$ BSA) was loaded onto plates $\left(4^{\circ} \mathrm{C}\right.$, overnight). Serially diluted anti-TNP-IgE antibodies were loaded as standards. The next day, after the plates were washed 5 times with PBS-T, the plates were incubated with biotin anti-mouse IgE (clone RME-1, at $2 \mu \mathrm{g} / \mathrm{ml}$ in $50 \mu \mathrm{l}, \mathrm{RT},>1 \mathrm{~h}$ ), and streptavidin-HRP (BioLegend, 405210; $1 \mu \mathrm{g} / \mathrm{ml},>30 \mathrm{~min}, \mathrm{RT})$. Plates were then washed 5 times with PBS-T. All ELISAs were developed using TMB Peroxidase Substrate (75 $\mu \mathrm{l} /$ well; Rockland and quenched with $2 \mathrm{M} \mathrm{H}_{2} \mathrm{SO}_{4}(75 \mu \mathrm{l} /$ well), and $\mathrm{A} 450$ was measured using a Synergy H1 plate reader (BioTek).

Human skin mast cells. Discarded skin tissues (abdominal skin, face and breast skin, and foreskin) from healthy donors who had undergone plastic surgery were cut into small pieces $(\sim 5 \mathrm{~mm})$ and soaked in RPMI 1640 supplemented with penicillin-streptomycin with $5 \mathrm{U} / \mathrm{ml}$ Dispase II (Roche) at $4^{\circ} \mathrm{C}$ overnight. The next day, the tissues were warmed up to $37^{\circ} \mathrm{C}$ for 2 hours and transferred to RPMI 1640 supplemented with Collagenase IV $(2.5 \mathrm{mg} / \mathrm{ml}$; Invitrogen, Thermo Fisher Scientific) and DNase I (0.5 mg/ml, Roche) for 45 minutes at $37^{\circ} \mathrm{C}$ with constant shaking. Disaggregated cells were then filtered through $70-\mu \mathrm{m}$ nylon cell strainers and cultured in StemPro-34 (Invitrogen, Thermo Fisher Scientific) overnight, followed by flow cytometric analysis. All Siglec antibodies and isotype controls were PE labeled and used at $2 \mu \mathrm{g} / \mathrm{ml}$. Human mast cells were defined as $\mathrm{PI}^{-} \mathrm{CD} 45^{+} \mathrm{CD} 19^{-} \mathrm{CD}^{-} \mathrm{CD}^{-} 6^{-} \mathrm{Fc} \varepsilon \mathrm{RI}^{+} \mathrm{c}-\mathrm{Kit}^{\mathrm{hi}}$. More than 800 events were collected within the mast cell gate.

Human airway bronchoconstriction assay. Precision cuts of human lung slices and airway constriction assays were conducted as previ- ously described (49). In brief, lung slices were sensitized with either human IgE (Calbiochem, 401152; $4 \mathrm{mg} / \mathrm{ml}$ overnight) or anti-TNPIgE (clone MEB38, BioLegend; $10 \mu \mathrm{g} / \mathrm{ml}$ overnight) in the presence of $200 \mathrm{ng} / \mathrm{ml}$ recombinant human SCF (R\&D Systems). After baseline images were taken, tissues were stimulated with anti-human IgE (Sigma-Alrich, I6284) or $50 \mu \mathrm{M}$ TNP-LP or TNP-LP-CD33L. Serial images were taken every 30 seconds for 10 minutes. Following cross-linking, the slices were tested for viability by measuring contraction induced by CCh (10 $10^{-4} \mathrm{M}$; Sigma-Aldrich, C4382). Data are plotted as the percentage of bronchoconstriction time course after addition of anti-IgE or liposomes (Figure 6C). The AUC (Figure 6D) was intergraded using GraphPad Prism (xy analysis) software (GraphPad Software), and values of less than 0 are plotted as 0 .

Statistics. Statistical significance was determined using GraphPad Prism (version 6.0f). A $P$ value of less than 0.05 was considered significant. In Figure 5B and Supplemental Figure 6, B and D, when mice died from anaphylaxis, the last rectal temperature taken prior to death was used for statistical analysis.

Study approval. All animal experiments were performed in accordance with protocols approved by the IACUC of The Scripps Research Institute.

\section{Author contributions}

$\mathrm{SD}, \mathrm{MSM}$, and JCP designed the experiments, analyzed the data, and interpreted the results. SD performed the majority of the experiments. CJKW, WFJ, and RAP designed and performed the human lung bronchoconstriction assay. CMN and MSM provided reagents for liposome formulation. SD and JCP wrote the initial draft of the manuscript. All authors participated in editing the manuscript.

\section{Acknowledgments}

We thank Sergey Kupriyanov and Greg Martin (The Scripps Research Institute) for their assistance with generation of the Rosa26-Stop ${ }^{f / f l}-C D 33$ mice; Bruce Bochner (Northwestern University, Chicago, Illinois, USA); Zhou Zhu (Brown University, Providence, Rhode Island) for insightful discussions and providing the Mcpt5-Cre and Ptpn $6^{f / f l}$ mice; Changchun Xiao and Jovan Shepherd (The Scripps Research Institute) for providing the CTV targeting vector and performing Southern blot analyses; Dean Metcalfe, Arnold Kirshenbaum, and Yun Bai (NIAID, NIH, Bethesda, Maryland, USA) for providing LAD2 cells; Mike Kulis and Wesley Burks (University of North Carolina at Chapel Hill, Chapel Hill, North Carolina, USA) for providing purified Ah2; Scott Smith (Vanderbilt University Medical Center, Nashville, Tennessee, USA) for providing anti-OVA-human IgE (clone 11B6); Wendy Havran and Kevin Ramirez (The Scripps Research Institute); Ross Rudolph (Scripps Clinic, San Diego, California, USA) for obtaining and providing the discarded human skin samples; and Joana Juan for assistance and Jill Waalen (The Scripps Research Institute) for advice on statistical analysis. This work was supported by the National Heart, Lung and Blood Institute (NHLBI), NIH (P01HL107151), the NIAID, NIH (U19AI136443), and the Department of Defense (W81XWH-16-1-0303).

Address correspondence to: James C. Paulson, 10550 N. Torrey Pines Road, MB202, La Jolla, California 92037, USA. Phone: 858.784.9634; Email: jpaulson@scripps.edu. 
1. Pawankar R. Allergic diseases and asthma: a global public health concern and a call to action. World Allergy Organ J. 2014;7(1):12.

2. NIAID-Sponsored Expert Panel, et al. Guidelines for the diagnosis and management of food allergy in the United States: report of the NIAID-sponsored expert panel. J Allergy Clin Immunol. 2010;126(6 Suppl):S1-S58.

3. Gupta RS, et al. The prevalence, severity, and distribution of childhood food allergy in the United States. Pediatrics. 2011;128(1):e9-e17.

4. Wood RA, et al. Anaphylaxis in America: the prevalence and characteristics of anaphylaxis in the United States. J Allergy Clin Immunol. 2014;133(2):461-467.

5. Galli SJ, Tsai M. IgE and mast cells in allergic disease. Nat Med. 2012;18(5):693-704.

6. Kalesnikoff J, Galli SJ. New developments in mast cell biology. Nat Immunol. 2008;9(11):1215-1223.

7. Gilfillan AM, Tkaczyk C. Integrated signalling pathways for mast-cell activation. Nat Rev Immunol. 2006;6(3):218-230.

8. Voehringer D. Protective and pathological roles of mast cells and basophils. Nat Rev Immunol. 2013;13(5):362-375.

9. Holgate ST, Polosa R. Treatment strategies for allergy and asthma. Nat Rev Immunol. 2008;8(3):218-230.

10. Lawrence MG, Woodfolk JA, Schuyler AJ, Stillman LC, Chapman MD, Platts-Mills TA. Half-life of $\operatorname{IgE}$ in serum and skin: Consequences for antiIgE therapy in patients with allergic disease. JAllergy Clin Immunol. 2017;139(2):422-428.e4.

11. Chang TW, Wu PC, Hsu CL, Hung AF. Anti-IgE antibodies for the treatment of IgE-mediated allergic diseases. Adv Immunol. 2007;93:63-119.

12. Wood RA. Food allergen immunotherapy: Current status and prospects for the future. JAllergy Clin Immunol. 2016;137(4):973-982.

13. Bauer RN, Manohar M, Singh AM, Jay DC, Nadeau KC. The future of biologics: applications for food allergy. J Allergy Clin Immunol. 2015;135(2):312-323.

14. Harvima IT, et al. Molecular targets on mast cells and basophils for novel therapies. J Allergy Clin Immunol. 2014;134(3):530-544.

15. Kraft S, Kinet JP. New developments in FcepsilonRI regulation, function and inhibition. Nat Rev Immunol. 2007;7(5):365-378.

16. Bachelet I, Munitz A, Levi-Schaffer F. Abrogation of allergic reactions by a bispecific antibody fragment linking IgE to CD300a. JAllergy Clin Immunol. 2006;117(6):1314-1320.

17. Zellweger F, Gasser P, Brigger D, Buschor P, Vogel M, Eggel A. A novel bispecific DARPin targeting Fc $\gamma$ RIIB and FceRI-bound IgE inhibits allergic responses. Allergy. 2017;72(8):1174-1183.

18. Eggel A, Buschor P, Baumann MJ, Amstutz P, Stadler BM, Vogel M. Inhibition of ongoing allergic reactions using a novel anti-IgE DARPin-Fc fusion protein. Allergy. 2011;66(7):961-968.

19. Zhu D, Kepley CL, Zhang M, Zhang K, Saxon A. A novel human immunoglobulin Fc gamma Fc epsilon bifunctional fusion protein inhibits Fc epsilon RI-mediated degranulation. Nat Med. 2002;8(5):518-521.

20. Liu Y, et al. Blockade of peanut allergy with a novel Ara h 2-Fc $\gamma$ fusion protein in mice. J Allergy
Clin Immunol. 2013;131(1):213-221.e1.

21. Zhu D, Kepley CL, Zhang K, Terada T, Yamada T, Saxon A. A chimeric human-cat fusion protein blocks cat-induced allergy. Nat Med. 2005;11(4):446-449.

22. Krauth MT, et al. Effects of the CD33-targeted drug gemtuzumab ozogamicin (Mylotarg) on growth and mediator secretion in human mast cells and blood basophils. Exp Hematol. 2007;35(1):108-116.

23. Yokoi H, Myers A, Matsumoto K, Crocker PR, Saito H, Bochner BS. Alteration and acquisition of Siglecs during in vitro maturation of CD34 $4^{+}$ progenitors into human mast cells. Allergy. 2006;61(6):769-776.

24. Macauley MS, Crocker PR, Paulson JC. Siglec-mediated regulation of immune cell function in disease. Nat Rev Immunol. 2014;14(10):653-666.

25. Crocker PR, Paulson JC, Varki A. Siglecs and their roles in the immune system. Nat Rev Immunol. 2007;7(4):255-266.

26. Macauley MS, et al. Antigenic liposomes displaying CD22 ligands induce antigen-specific B cell apoptosis. J Clin Invest. 2013;123(7):3074-3083.

27. Pfrengle F, Macauley MS, Kawasaki N, Paulson JC. Copresentation of antigen and ligands of Siglec-G induces B cell tolerance independent of CD22. JImmunol. 2013;191(4):1724-1731.

28. Orgel KA, et al. Exploiting CD22 on antigenspecific B cells to prevent allergy to the major peanut allergen Ara h 2.J Allergy Clin Immunol. 2017;139(1):366-369.e2.

29. Bednar KJ, et al. Human CD22 inhibits murine $\mathrm{B}$ cell receptor activation in a human CD22 transgenic mouse model. Jimmunol. 2017;199(9):3116-3128.

30. Rillahan CD, et al. Disubstituted sialic acid ligands targeting Siglecs CD33 and CD22 associated with myeloid leukaemias and B cell lymphomas. Chem Sci. 2014;5(6):2398-2406.

31. Macglashan D, Miura K. Loss of syk kinase during IgE-mediated stimulation of human basophils. JAllergy Clin Immunol. 2004;114(6):1317-1324.

32. Platzer B, Fiebiger E. The signal peptide of the IgE receptor alpha-chain prevents surface expression of an immunoreceptor tyrosine-based activation motif-free receptor pool. J Biol Chem. 2010;285(20):15314-15323.

33. Oka T, Rios EJ, Tsai M, Kalesnikoff J, Galli SJ. Rapid desensitization induces internalization of antigen-specific IgE on mouse mast cells. J Allergy Clin Immunol. 2013;132(4):922-932.e1.

34. Thai TH, et al. Regulation of the germinal center response by microRNA-155. Science. 2007;316(5824):604-608.

35. Scholten J, et al. Mast cell-specific Cre/loxPmediated recombination in vivo. Transgenic Res. 2008;17(2):307-315.

36. Dudeck A, et al. Mast cells are key promoters of contact allergy that mediate the adjuvant effects of haptens. Immunity. 2011;34(6):973-984.

37. Kuehn HS, Radinger M, Gilfillan AM. Measuring mast cell mediator release. Curr Protoc Immunol. 2010; Chapter 7:Unit7.38.

38. Field KA, Holowka D, Baird B. Compartmentalized activation of the high affinity immunoglobulin E receptor within membrane domains. J Biol
Chem. 1997;272(7):4276-4280.

39. Kitaura J, Asai K, Maeda-Yamamoto M, Kawakami Y, Kikkawa U, Kawakami T. Akt-dependent cytokine production in mast cells. J Exp Med. 2000;192(5):729-740.

40. Poderycki M, et al. A minor catalytic activity of Src family kinases is sufficient for maximal activation of mast cells via the high-affinity IgE receptor. JImmunol. 2010;184(1):84-93.

41. Ulyanova T, Blasioli J, Woodford-Thomas TA, Thomas ML. The sialoadhesin CD33 is a myeloid-specific inhibitory receptor. Eur J Immunol. 1999;29(11):3440-3449.

42. Taylor VC, Buckley CD, Douglas M, Cody AJ, Simmons DL, Freeman SD. The myeloid-specific sialic acid-binding receptor, CD33, associates with the protein-tyrosine phosphatases, SHP-1 and SHP-2. J Biol Chem . 1999;274(17):11505-11512.

43. Pao LI, et al. B cell-specific deletion of proteintyrosine phosphatase Shp1 promotes B-1a cell development and causes systemic autoimmunity. Immunity. 2007;27(1):35-48.

44. Caubet JC, Wang J. Current understanding of egg allergy. Pediatr Clin North Am. 2011;58(2):427-743.

45. Cheng LE, Wang ZE, Locksley RM. Murine B cells regulate serum IgE levels in a CD23-dependent manner. JImmunol. 2010;185(9):5040-5047.

46. Dahl C, Hoffmann HJ, Saito H, Schiøtz PO. Human mast cells express receptors for IL-3, IL-5 and GM-CSF; a partial map of receptors on human mast cells cultured in vitro. Allergy. 2004;59(10):1087-1096.

47. Krauth MT, et al. Cell surface membrane antigen phenotype of human gastrointestinal mast cells. Int Arch Allergy Immunol. 2005;138(2):111-120.

48. Escribano L, et al. Indolent systemic mast cell disease in adults: immunophenotypic characterization of bone marrow mast cells and its diagnostic implications. Blood. 1998;91(8):2731-2736.

49. Koziol-White CJ, et al. Inhibition of spleen tyrosine kinase attenuates IgE-mediated airway contraction and mediator release in human precision cut lung slices. Br J Pharmacol. 2016;173(21):3080-3087.

50. Krishna MT, Huissoon AP. Clinical immunology review series: an approach to desensitization. Clin Exp Immunol. 2011;163(2):131-146.

51. MacGinnitie AJ, et al. Omalizumab facilitates rapid oral desensitization for peanut allergy. J Allergy Clin Immunol. 2017;139(3):873-881.e8.

52. Andorf S, et al. Anti-IgE treatment with oral immunotherapy in multifood allergic participants: a double-blind, randomised, controlled trial. Lancet Gastroenterol Hepatol. 2018;3(2):85-94.

53. Guyer BJ, Shimamoto SR, Bradhurst AL, Grossbard EB, Dreskin SC, Nelson HS. Mast cell inhibitor R112 is well tolerated and affects prostaglandin D2 but not other mediators, symptoms, or nasal volumes in a nasal challenge model of allergic rhinitis. Allergy Asthma Proc. 2006;27(3):208-213.

54. Burton OT, et al. Immunoglobulin E signal inhibition during allergen ingestion leads to reversal of established food allergy and induction of regulatory T cells. Immunity. 2014;41(1):141-151.

55. Regan JA, et al. Ibrutinib, a Bruton's tyrosine kinase inhibitor used for treatment of lymphoproliferative disorders, eliminates both aeroallergen 
skin test and basophil activation test reactivity. JAllergy Clin Immunol. 2017;140(3):875-879.e1.

56 . Shimanaka $Y$, et al. Omega-3 fatty acid epoxides are autocrine mediators that control the magnitude of IgE-mediated mast cell activation. Nat Med. 2017;23(11):1287-1297.

57. Monino-Romero $S$, et al. The soluble isoform of human FcvarepsilonRI is an endogenous inhibitor of IgE-mediated mast cell responses [published online ahead of print July 21, 2018]. Allergy. https://doi.org/10.1111/all.13567.

58. Laszlo GS, Estey EH, Walter RB. The past and future of CD33 as therapeutic target in acute myeloid leukemia. Blood Rev. 2014;28(4):143-153.

59. Kim MY, et al. Genetic inactivation of CD33 in hematopoietic stem cells to enable CAR T cell immunotherapy for acute myeloid leukemia. Cell. 2018;173(6):1439-1453.e19.
60. Hitomi K, et al. An immunoglobulin-like receptor, Allergin-1, inhibits immunoglobulin E-mediated immediate hypersensitivity reactions. Nat Immunol.2010;11(7):601-607.

61. Burton OT, et al. Tissue-specific expression of the low-affinity IgG receptor, Fc $\gamma$ RIIb, on human mast cells. Front Immunol. 2018;9:1244.

62. Zenarruzabeitia O, Vitallé J, Eguizabal C, Simhadri VR, Borrego F. The biology and disease relevance of CD300a, an inhibitory receptor for phosphatidylserine and phosphatidylethanolamine. J Immunol. 2015;194(11):5053-5060.

63. Mizrahi S, Gibbs BF, Karra L, Ben-Zimra M, Levi-Schaffer F. Siglec-7 is an inhibitory receptor on human mast cells and basophils. J Allergy Clin Immunol. 2014;134(1):230-233.

64. Avril T, Floyd H, Lopez F, Vivier E, Crocker PR. The membrane-proximal immunoreceptor tyrosine-based inhibitory motif is critical for the inhibitory signaling mediated by Siglecs- 7 and -9, CD33-related Siglecs expressed on human monocytes and NK cells. J Immunol. 2004;173(11):6841-6849.

65. Yokoi H, et al. Inhibition of FcepsilonRIdependent mediator release and calcium flux from human mast cells by sialic acid-binding immunoglobulin-like lectin 8 engagement. JAllergy Clin Immunol. 2008;121(2):499-505.e1.

66. Brownstein DG. Manipulating the Mouse Embryo: A Laboratory Manual. Third Edition. In: Nagy A, Gertsenstein M, Vintersten K, Behringer R, eds. The Quarterly Review of Biology. 2003;78(3):365.

67. Scholten J, et al. Mast cell-specific Cre/loxPmediated recombination in vivo. Transgenic Res. 2008;17(2):307-315. 